\title{
The role of ubiquitin-specific peptidases in cancer progression
}

\author{
Ming-Jer Young ${ }^{1}$, Kai-Cheng Hsu' 2,3,4 Tony Eight Lin ${ }^{3}$, Wen-Chang Chang ${ }^{6}$ and Jan-Jong Hung ${ }^{1,5^{*}}$ (D)
}

\begin{abstract}
Protein ubiquitination is an important mechanism for regulating the activity and levels of proteins under physiological conditions. Loss of regulation by protein ubiquitination leads to various diseases, such as cancer. Two types of enzymes, namely, E1/E2/E3 ligases and deubiquitinases, are responsible for controlling protein ubiquitination. The ubiquitin-specific peptidases (USPs) are the main members of the deubiquitinase family. Many studies have addressed the roles of USPs in various diseases. An increasing number of studies have indicated that USPS are critical for cancer progression, and some USPS have been used as targets to develop inhibitors for cancer prevention. Herein we collect and organize most of the recent studies on the roles of USPs in cancer progression and discuss the development of USP inhibitors for cancer therapy in the future.
\end{abstract}

Keywords: Ubiquitination, Deubiquitinases, Ubiquitin-specific peptidases, Cancer

\section{Background}

After translation, most proteins can undergo various modifications, namely, phosphorylation, acetylation, methylation, sumoylation, glycosylation and ubiquitination, to modulate their activity. Posttranslational modification (PTM) of proteins is an important component of all physiological processes that functions by regulating various pathways, including protein degradation, DNA repair activity, gene regulation and signal transduction [1]. Evolutionarily higher plants and animals have more complex PTMs, indicating that the PTM process is beneficial to supporting the progression of life [2]. Ubiquitin is a small 76-amino-acids protein that can be conjugated to specific target proteins in various forms, namely, polyubiquitination and monoubiquitination. Three types of enzymes, namely, ubiquitin-activating enzymes (E1s), ubiquitin-conjugating enzymes (E2s), and ubiquitin ligases (E3s), are responsible for adding the ubiquitin into target proteins [3]. Seven lysine residues in ubiquitin provide different types of linkages, including monoubiquitination, polyubiquitination and branched ubiquitination, to regulate the different functions of target proteins [4]. Protein

\footnotetext{
* Correspondence: petehung@mail.ncku.edu.tw

${ }^{1}$ Department of Biotechnology and Bioindustry Sciences, National Cheng

Kung University, Tainan 701, Taiwan

${ }^{5}$ The Ph.D. Program for Neural Regenerative Medicine, Taipei Medical

University, Taipei, Taiwan

Full list of author information is available at the end of the article
}

monoubiquitination affects DNA repair activity, gene regulation, molecule trafficking and endocytosis [5]. Lys48-linked protein polyubiquitination affects protein degradation in a $26 \mathrm{~S}$ proteasome-dependent manner. Lys63-linked protein polyubiquitination is involved in DNA repair activity, signal transduction, trafficking and endocytosis [6]. Branched ubiquitination of proteins, such as in the APC/C complex, is also associated with $26 \mathrm{~S}$ proteasome-dependent degradation [4]. All types of ubiquitination as a protein modification are crucial to maintaining normal physiological conditions [7]. Dysregulation of protein ubiquitination leads to many diseases, including degenerative diseases and cancer $[8,9]$.

Deubiquitinases (DUBs) are a group of enzymes that are able to remove ubiquitin from ubiquitinated proteins, including monoubiquitinated, polyubiquitinated and branch polyubiquitinated proteins, leading to the regulation of the stability or activity of the target proteins $[10,11]$. More than one hundred deubiquitinases that regulate all protein deubiquitination have been identified in humans. DUB members can be divided into five types: ubiquitin-specific proteases (USPs), ovarian tumor proteases (OTUs), ubiquitin C-terminal hydrolases (UCHs), Machado-Joseph disease protein domain proteases (MJDs) and JAMM motif proteases [12, 13]. USPs, OTUs, UCHs and MJDs are cysteine-dependent proteases $[14,15]$. The JAMM motif is a metal-dependent protease 
$[14,15]$. Most of these enzymes exert their functions by reversing the polyubiquitination or monoubiquitination of target proteins. An increasing number of studies have indicated that dysregulation of the DUB causes malfunction of the ubiquitin system, which can either increase the effects of oncogenes or decrease the tumor suppressor gene activity. Herein we collected and organized all recent studies that address the roles of each USP in cancer progression.

\section{The roles of USPs in tumorigenesis}

Many studies indicate that USPs regulate tumor formation by modulating the proliferation and death of cancer cells. All USPs and their substrates are shown in Table 1.

\section{USPs are involved in cell cycle progression}

Protein ubiquitination is important for the regulation of cell cycle progression. Ubiquitinases, namely, E1/E2/E3, are well studied. Recently, several deubiquitinases have been reported to be involved in cell cycle progression. USP2 and USP22 can stabilize cyclin D1 to promote cell cycle progression $[16,17]$. A recent study also revealed that a small molecule, ML364, can inhibit USP2 to promote degradation, leading to cell cycle arrest [18]. USP7 has been reported to promote the growth of non-small cell lung cancer cells by stabilizing Ki-67 protein [19]. However, metformin can inhibit esophageal cancer proliferation through the upregulation of USP7, suggesting that USP7 has different effects on tumorigenesis in the different cancer types [20-22]. USP24 stabilizes securin to block the cell cycle progression from metaphase to anaphase, leading to cell cycle arrest [23]. According to previous studies, APCC, as an E3-ligase in mitosis, regulates many factors, including securin, to promote cell cycle progression [24]. In addition to E3-ligases, deubiquitinases, such as USP24, may also be important for cell cycle progression [23]. More evidence is needed to support the hypothesis that downregulation of USP24 in mitosis is induced by APCC. USP37 also regulates the stability of oncogenic fusion protein PLZF/RARA [25]. USP37 links REST to the control of p27 stability and cell proliferation [26]. USP44 promotes prostate cancer tumorigenesis by stabilizing EZH2 [27]. USP44 also induces DNA aneuploidy in gastric cancer, which may induce cell cycle arrest and apoptosis [28]. Therefore, USP44 is a tumor suppressor against chromosome missegregation [29]. In addition, USP44 function as an integral component of N-CoR to regulate gene expression [30].

\section{USPs-stabilized c-Myc promotes cancer formation}

$\mathrm{c}-\mathrm{Myc}$ is an oncogene that regulates gene expression and cell cycle progression. USP2 is reported to be involved in activating the c-Myc pathway to regulate prostate cancer formation [31]. USP10 can stabilize c-Myc expression [32]. USP22 promotes the proliferation, migration and invasion abilities of glioma, gastric cancer and colorectal cancer [33-35]. In addition, USP22 stabilizes c-Myc to promote breast cancer progression [36]. USP28 contributes to the proliferation and metastasis of gastric cancer [37]. The loss of USP28 enhances the radiosensitivity of esophageal cancer cells via the c-Myc pathway [38]. USP36 stabilizes c-Myc to promote ovarian cancer formation [39]. USP37 directly stabilizes c-Myc in lung cancer [40]. All the studies reveal that USPs are important in regulating c-Myc stability during tumorigenesis.

\section{USPs regulate apoptosis-related factors}

p53 is a tumor suppressor, and p53 degradation or mutations are critical factors in cancer formation [41]. Several E3 ligases, such as MDM2, have been well studied [42]. Recent studies have also indicated that several deubiquitinases are involved in the regulation of p53 degradation [43]. USP2 and USP7 stabilize MDM2 and MDM4 to degrade p53, leading to an anti-apoptosis phenotype [44-46]. USP4 and USP5 inhibit p53 expression, but the molecular mechanism has yet to be elucidated [47-49]. USP10 can interact with G3BP2 to block p53 signaling and subsequently contributes to a poor prostate cancer prognosis [50]. However, in lung cancer, USP10 can inhibit cell growth and invasion by stabilizing PTEN, suggesting that the roles of USP10 in the different cancer types are distinct [51]. USP15 stabilizes MDM2 to regulate p53 and NFATc2 in cancer cells and $\mathrm{T}$ cells, respectively, resulting in tumor cell apoptosis and antitumor $\mathrm{T}$ cell responses [52]. USP24 can stabilize p53 but not c-Myc to inhibit tumorigenesis. USP42 was reported to stabilize TP53, but USP42 knockdown inhibits cancer formation, implying that other unknown factors related to cancer formation may exist [53]. USP2 stabilizes MDM2 and MDM4 to inhibit the Fas/p53 pathway during tumorigenesis $[46,54]$. USP5 inhibits the p53 pathway [55]. USP7, USP10 and USP24 can stabilize p53 to inhibit cancer formation [45, 56, 57]. Our previous studies indicated that USP24 is downregulated in patients with early stage lung cancer. Overexpression of USP24 induces apoptosis by stabilizing securin and Bax, respectively [23]. USP27X stabilizes BCL2L11 to increase the anti-apoptotic effects of MAPK activity [58]. USP30 also participates in inhibiting apoptosis by stabilizing Parkin [59].

\section{The roles of USPs in cancer malignancy}

Disrupted regulation of protein ubiquitination is a trigger of various diseases, including cancer. An increasing number of USPs have been shown to be involved in cancer malignancy. All USPs that are involved in cancer 
Table 1 Human ubiquitin specific proteases (USPS) and their reported functions in the cancer progression

\begin{tabular}{|c|c|c|c|c|c|}
\hline Gene symbol & Cellular location & Substrate & $\begin{array}{l}\text { Function and remarks in } \\
\text { cancer }\end{array}$ & Inhibitor & References \\
\hline USP1 & $N$ & $\begin{array}{l}\text { FANCD2 } \\
\text { PCNA }\end{array}$ & DNA repair; Oncogene & $\begin{array}{l}\text { Pimozideb, ML323, } \\
\text { GW7647, C527, 6- } \\
\text { Amino-pyrimidines, } \\
\text { SJB2-043, SJB3-019A, } \\
\text { PR619 }\end{array}$ & {$[92,110-114]$} \\
\hline USP2 & $\mathrm{C}, \mathrm{N}$ & $\begin{array}{l}\text { Fatty acid synthase, } \\
\text { cyclin D1, MDM2 and } 4\end{array}$ & $\begin{array}{l}\text { Fas/p53, NF-kB, } \\
\text { c-Myc; Oncogene }\end{array}$ & $\begin{array}{l}\text { NSC632839, AM146, } \\
\text { RA-9, RA-14, 2-cyano- } \\
\text { pyrimidines and - } \\
\text { triazines', ML364, PR619 }\end{array}$ & {$[18,31,44,114-122]$} \\
\hline USP3 & N & $\mathrm{H} 2 \mathrm{~A}, \mathrm{H} 2 \mathrm{~B}$ & DDR, Oncogene & & [123-125] \\
\hline USP4 & $C, N$ & TRAF2, TRAF6 & $\begin{array}{l}\text { TGF } \beta \text {, NFkB, Wnt, } \\
\text { p53; Oncogene }\end{array}$ & Vialinin A, PR619 & {$[81,114,126-128]$} \\
\hline USP5 & $L, V, C^{a}$ & & p53, DDR, Oncogene & $\begin{array}{l}\text { G9, Vialinin A, } \\
\text { WP1130, EOAl3402143, } \\
\text { AM146, RA-9, RA-14, } \\
\text { PR619 }\end{array}$ & $\begin{array}{l}{[49,93,106,114,118,127} \\
129-132]\end{array}$ \\
\hline USP6 & Golgi, C & & $\begin{array}{l}\text { NFKB activation; } \\
\text { Oncogene } \\
\text { or Suppressor }\end{array}$ & & [133] \\
\hline USP7 & N, C, PML body & $\begin{array}{l}\text { HDM2, p53, H2B, TP53, } \\
\text { MDM2 \& 4, FOXO4, } \\
\text { PTEN }\end{array}$ & Oncogene & $\begin{array}{l}\text { P5091, Cpd14, } \\
\text { P22077, HBX41108, } \\
\text { HBX 19818, HBX } \\
\text { 28258, NSC632839, } \\
\text { WO2013030218, } \\
\text { P0050429, } \\
\text { W02013030218, } \\
\text { PR619 }\end{array}$ & {$[114,117,121,134-146]$} \\
\hline USP8 & $\mathrm{C}, \mathrm{N}$ & NRDP1, RNF128, STAM2 & Oncogene & $\begin{array}{l}\text { HBX90397, HBX41108, } \\
\text { AM146, RA-9, RA-14, } \\
\text { Ethyloxyimino-9H- } \\
\text { indeno[1,2-b] } \\
\text { pyrazine-2,3- } \\
\text { dicarbonitrile, PR619 }\end{array}$ & {$[95,114,118,147-150]$} \\
\hline USP9X & $C, E, L, V$ & $\begin{array}{l}\beta \text {-catenin, epsins, AF-6, } \\
\text { SMAD2 }\end{array}$ & $\begin{array}{l}\text { TGF } \beta \text {, MCl-1, ERG, AGS-3, } \\
\text { ITCH, Wnt, Notch; } \\
\text { Oncogene or suppressor }\end{array}$ & G9, WP1130, PR619 & $\begin{array}{l}{[106,107,114,130-132,151-} \\
154]\end{array}$ \\
\hline USP9Y & C & & Spematogenesis & & [155] \\
\hline USP10 & $\mathrm{C}, \mathrm{N}$ & TP53, SNX3, CFTR & $\begin{array}{l}\text { c-Myc, p53; Oncogene } \\
\text { or suppressor }\end{array}$ & $\begin{array}{l}\text { P22077, HBX19818, } \\
\text { Spautin-1, PR619 }\end{array}$ & {$[32,56,114,156-158]$} \\
\hline USP11 & $\mathrm{N}, \mathrm{C}$ & BRCA2, NFKBIA & $\mathrm{DDR}, \mathrm{NF} \mathrm{KB}$; Oncogene & Mitoxantrone ${ }^{b}$ & {$[70,104,159-161]$} \\
\hline USP12 & & Androgen receptor & Oncogene & GW7647 & {$[92,162-164]$} \\
\hline USP13 & $L, V, C, N^{a}$ & MCL1, BECN1, USP10 & & Spautin-1 & {$[157,165-167]$} \\
\hline USP14 & C, PM & & Wnt; Oncogene & $\begin{array}{l}\text { VLX1570', IU1, } \\
\text { WP1130, b-AP15, } \\
\text { AC17, Auranofin', } \\
\text { Tricyclic heterocyclics, } \\
\text { Azepan-4-ones, } \\
\text { PR619 }\end{array}$ & {$[106,114,132,168-175]$} \\
\hline USP15 & $\mathrm{C}, \mathrm{N}$ & RBX1, SMAD1, 2, $3 \& 7$ & NFkB, Wnt; Oncogene & PR619 & {$[114,176-179]$} \\
\hline USP16 & $N$ & $\mathrm{H} 2 \mathrm{~A}$ & $\begin{array}{l}\text { Chromosome } \\
\text { condensation; } \\
\text { Oncogene }\end{array}$ & PR619 & {$[114,180-183]$} \\
\hline USP17 & & SUDS3 & Oncogene & & [184-186] \\
\hline USP18 & $\mathrm{C}, \mathrm{N}$ & TAK1, TAB1, PTEN & $\begin{array}{l}\text { JAK-STAT, NFKB; } \\
\text { Oncogene }\end{array}$ & & {$[187,188]$} \\
\hline USP19 & $E R$ & RNF123 & ERAD & PR619 & {$[114,189-191]$} \\
\hline
\end{tabular}


Table 1 Human ubiquitin specific proteases (USPs) and their reported functions in the cancer progression (Continued)

\begin{tabular}{|c|c|c|c|c|c|}
\hline Gene symbol & Cellular location & Substrate & $\begin{array}{l}\text { Function and remarks in } \\
\text { cancer }\end{array}$ & Inhibitor & References \\
\hline USP20 & $\mathrm{C}, \mathrm{N}$ & DIO2, ADRB2, TRAF6, Tax & $\begin{array}{l}\text { Thyroid hormone, } \\
\text { hypoxia, NFkB; } \\
\text { Oncogene }\end{array}$ & PR619 & {$[114,192,193]$} \\
\hline USP21 & $\mathrm{C}, \mathrm{N}$ & $\begin{array}{l}\text { H2A, RIPK1, DDX58, } \\
\text { GATA3, IL33 }\end{array}$ & $\begin{array}{l}\text { NFKB, NEDD8; } \\
\text { Oncogene }\end{array}$ & & {$[72,194-198]$} \\
\hline USP22 & N & $\mathrm{H} 2 \mathrm{~A}$ & c-Myc; Oncogene & PR619 & {$[114,199-202]$} \\
\hline USP24 & C & $\begin{array}{l}\text { TP53, DDB2, MCL1, Bax, } \\
\text { p300, E2F4, securin, } \\
\beta \operatorname{TrCP}\end{array}$ & $\begin{array}{l}\text { Cell growth repressor; } \\
\text { Metastasis promoter; } \\
\text { Overexpression in M2 } \\
\text { macrophages }\end{array}$ & G9, PR619 & $\begin{array}{l}{[23,57,75,106,114,130,131} \\
203]\end{array}$ \\
\hline USP25 & $\mathrm{C}, \mathrm{N}$ & DDX58 & ERAD; Oncogene & & [204-206] \\
\hline USP26 & $\mathrm{N}$ (testis) & $A R$ & Spermatogenesis & & [207-209] \\
\hline USP27X & & BCL2L11 & tumor suppressor & & {$[58,210]$} \\
\hline USP28 & N & & $\begin{array}{l}\text { CLSPN, C-MYC; } \\
\text { Oncogene or suppressor }\end{array}$ & PR619 & {$[114,211,212]$} \\
\hline USP29 & $N^{a}$ & & p53 pathway; Oncogene & & {$[213,214]$} \\
\hline USP30 & M & $\begin{array}{l}\text { MFN1, MFN2, DRP1, } \\
\text { Parkin }\end{array}$ & Hepatocarcinogenesis & & {$[215-217]$} \\
\hline USP31 & $\mathrm{N}, \mathrm{C}$ & & Inhibition of NFKB & & [218] \\
\hline USP32 & PM, Golgi & & Oncogene & & [219] \\
\hline USP33 & $\mathrm{C}, \mathrm{N}$, centrosome & $\begin{array}{l}\text { HIF1-a DIO2, ADRB2, } \\
\text { CCP110, ARRB }\end{array}$ & Tumor suppressor & & {$[192,220-223]$} \\
\hline USP34 & $\begin{array}{l}\mathrm{C}, \mathrm{N}, \mathrm{PM}, \\
\text { Extracellular }\end{array}$ & AXIN1, AXIN2, & $\begin{array}{l}\text { Activation of Wnt; } \\
\text { Inhibition of } \\
\text { EMT and cancer } \\
\text { stemness }\end{array}$ & & {$[102,224]$} \\
\hline USP35 & $N^{a}$ & ABIN-2, Aurora B & $\begin{array}{l}\text { Tumor suppressor } \\
\text { through } \\
\text { inactivating NFKB }\end{array}$ & & {$[225,226]$} \\
\hline USP36 & $N$ & c-Myc & Oncogene & & \\
\hline USP37 & $N$ & c-Myc & $\begin{array}{l}\text { Increase in DNA damage } \\
\text { repair; } \\
\text { Oncogene }\end{array}$ & & \\
\hline USP38 & $C, N, G A^{a}$ & & & & \\
\hline USP39 & N & & Oncogene & & \\
\hline USP40 & $C, N, P M$ & & & & \\
\hline USP41 & $N^{a}$ & & & & \\
\hline USP42 & $N^{a}$ & TP53 & p53; Oncogene & & {$[53,227,228]$} \\
\hline USP43 & $N^{a}$ & H2BK120 & Tumor suppressor & & \\
\hline USP44 & N & CDC20, EZH2 & Oncogene & & [229] \\
\hline USP45 & $C, N$ & & & & \\
\hline USP46 & $L, V^{a}$ & & Oncogene & Pimozide $^{b}$ & [113] \\
\hline USP47 & C & POLB & Oncogene & $\begin{array}{l}\text { P5091, Cpd14, } \\
\text { P22077, PR619 }\end{array}$ & {$[114,136,137,139,230]$} \\
\hline USP48 & $\mathrm{C}, \mathrm{N}$ & Gli1 & Oncogene & PR619 & [114] \\
\hline USP49 & N & $\mathrm{H} 2 \mathrm{~B}$ & Tumor suppressor & & [231] \\
\hline USP50 & $N^{a}$ & & G2/M checkpoint & & [232] \\
\hline USP51 & $N^{a}$ & & & & \\
\hline PAN2 & $\mathrm{C}, \mathrm{N}$ & & & & \\
\hline
\end{tabular}


Table 1 Human ubiquitin specific proteases (USPs) and their reported functions in the cancer progression (Continued)

\begin{tabular}{|c|c|c|c|c|}
\hline Gene symbol & Cellular location & Substrate & $\begin{array}{l}\text { Function and remarks in Inhibitor } \\
\text { cancer }\end{array}$ & References \\
\hline USP53 & Golgi, $N^{a}$ & & & \\
\hline USP54 & $M^{a}$ & & Oncogene & \\
\hline USPL1 & N, Cajal body & & & \\
\hline DUB3 & & $\mathrm{H} 2 \mathrm{AX}$ & $\begin{array}{l}\text { G2/M checkpoint; } \\
\text { Cancer associated }\end{array}$ & {$[233,234]$} \\
\hline CYLD & $C, N, P M$ & $\begin{array}{l}\text { TRAF2/6, NEMO, TRPA1, } \\
\text { Tak1, LCK, } \\
\text { Bcl3, DVl, DDX58, } \\
\text { K63polyUb-RIPK1, } \\
\text { K63polyU } 3-I K B K G\end{array}$ & $\begin{array}{l}\text { NFKB and JNK-STAT; } \\
\text { Familial tumor } \\
\text { suppressor }\end{array}$ & {$[68,235-239]$} \\
\hline
\end{tabular}

The roles of USPs in the cancer progression. ${ }^{a}$ predicted; C: Cytoplasm; N: Nucleus; L: Lysosome; V: Vacuole; ER: Endoplasmic reticulum; M: Mitochondria; E: Endosome; ${ }^{\text {b } C l i n i c ~ t r i a l ~ o n ~ g o i n g ~(h t t p s: / / c l i n i c a l t r i a l s . g o v / c t 2 / h o m e) ~}$

malignancy through the regulation of different pathways are then discussed.

\section{USPs are involved in EMT and the stemness of cancer} USP11 stabilizes Snail to promote EMT in ovarian cancer [60]. USP24 also enhances TGFß-induced EMT and metastasis of breast cancer [61]. Several previous studies have indicated that USP21 affects stem cells by stabilizing Nanog and IL8 [62]. Inhibition of USP34 induces EMT and stemness in mammary epithelial cells [63]. Previous reports indicated that USP47 promotes colorectal cancer EMT and malignancy by stabilizing Snail and activating the Wnt signaling pathway [64].

\section{USPs regulate related pathways to control cancer metastasis}

According to previous studies, several important cancerrelated pathways are regulated by various USP members.

The JNKs-STATs compose an important pathway for cancer malignancy. Recent studies indicated that STAT3 activation represses USP7, leading to colon cancer development [65]. Another recent study indicated that USP3 mRNA functioned as a sponge for miR-224 to increase the level of SMAD4, resulting in colorectal cancer metastasis [66]. However, the role of USP3, as a deubiquitinase, is still not known [67]. CYLD controls c-Myc expression through a JNK-dependent signaling pathway in hepatocellular carcinoma [68].

The NFKB pathway is important for physiological and pathological progression, including inflammation and cancer progression. Many recent studies have shown that ubiquitination regulates not only protein degradation but also protein activity by modulating the interaction between proteins. Several USPs have been reported to be involved in the NFKB pathway [69]. USP6 is involved in the activation of the NFkB pathway, thus positively regulating tumorigenesis; however, the molecular mechanism is not yet known. USP11 can nega-

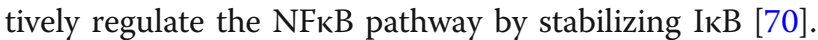

USP18 inhibits the NFKB pathway by targeting TAK1 and NEMO for deubiquitination [71]. USP21 stabilizes IL33 to increase the signal transduction of NFKB [72]. Many studies have revealed that CYLD can inhibit NFkB signal transduction by regulating various factors, such as TRAF2/6, NEMO and Tak1 [73]. The polyubiquitination of TRAFs can increase the recruitment of other related proteins to induce the NFKB signaling pathway. USP4 and USP20 can promote the cell migration and invasion activities in breast cancer by inhibiting $\mathrm{NF}_{\kappa} \mathrm{B}$ activation via deubiquitination of TRAF2 and TRAF6 [74]. Our recent study also indicated that USP24 can induce the $\mathrm{NF} \kappa \mathrm{B}$ pathway by stabilizing the $\beta \operatorname{TrCP}$, which is the E3-ligase of IKB and DNMT1, causing the degradation of IкB and DNMT1 [75]. Regulation of USP35 by the miR let-7a can inhibit NFKB activation via deubiquitination and stabilization of $\mathrm{ABIN}-2$ protein to inhibit cancer progression [76].

The TGF $\beta$ pathway is involved in several aspects of cancer progression, including cancer malignancy [77]. Different USPs regulate the TGF $\beta$ pathway by stabilizing different factors in this pathway [78]. USP4 and USP15 can stabilize TGF $\beta$ receptor type 1 to increase TGF $\beta$-mediated EMT, leading to metastasis of hepatocellular carcinoma and glioblastoma [79-81]. A recent study indicated that a long noncoding RNA, H19, can compete with the binding of miR-148a to USP4 mRNA to increase the signaling activity of TGF $\beta$ [82]. USP9X can control the monoubiquitination of SMAD4 to regulate TGF $\beta$-mediated cancer metastasis [83]. According to previous studies, USPs are crucial for the regulation of the TGF $\beta$-mediated pathway [84].

The Wnt pathway is important for cancer EMT and metastasis [85]. USP4 can positively regulate the Wnt signaling in colorectal cancer [86]. Previous studies indicated that USP9X increases adhesion by destabilizing $\beta$-catenin [87]. USP14 and USP34 are required for Wnt signaling, but the detailed molecular mechanism is not yet known [88]. 
USPs are involved in the tumor-associated microenvironment Our recent study found that USP24 is increased in M2 tumor-associated macrophages (TAMs), thereby promoting lung cancer malignancy through an increase in IL6 expression [75]. Increasing evidence indicates that TAMs are important for cancer malignancy and drug resistance [89-91]. Therefore, more USPs that are involved in regulating the tumor-associated microenvironment are expected to be identified in the future.

\section{The roles of USPs in DNA damage repair activity}

DNA damage repair activity is related to the genomic integrity. A decrease in the DNA damage repair activity causes drug resistance under drug treatment, such as chemotherapy. According to recent studies, many deubiquitinases are involved in DNA damage repair pathways, indicating that deubiquitinases may be important for the induction of drug resistance. USP1 participates in restoring sensitivity to cisplatin in drug-resistance lung cancer cells by stabilizing FANCD2 [92]. USP3, 5 and 11 have been reported to be involved in increasing DNA damage repair activity by activating the DDR pathway [67, 93, 94]. USP8 may participate in TKI-induced drug resistance by increasing the levels of several receptor tyrosine kinases, including EGFR, ERBB2, ERBB3, and MET [95]. However, no substrate has been found to date. A recent study indicated that USP14 may be involved in cisplatin resistance by modulating the Akt/ERK signaling pathway in gastric cancer [96]. USP21 increases DNA repair and tumor growth by stabilizing BRCA2 [97]. USP22 promotes resistance to EGFR-TKIs by stabilizing EGFR in EGFR-mutant lung adenocarcinoma [98]. A recent study also indicated that the loss of USP22 causes to myeloid leukemia upon Kras activation through a PU.1-dependent mechanism [99]. USP22 induces cisplatin resistance in lung cancer by regulating $\gamma \mathrm{H} 2 \mathrm{AX}$-mediated DNA damage repair and Ku70/Bax-mediated apoptosis [100]. USP22 knockdown increases the chemosensitivity of hepatocellular carcinoma cells to 5-FU by upregulating Smad4 and suppressing Akt [101]. USP26 is involved in the HR-dependent repair pathway. USP34 inhibits EMT and cancer stemness and may therefore induce more resistance to the drug treatment [102]. USP26 and USP37 participate in HR repair pathway by counteracting RAP80 [103]. USP47 promotes gastric cancer growth by regulating RelA. Many USPs discussed here are involved in DNA damage repair pathways, suggesting that USPs may be the potential targets for drug development of drug resistance in the future.

USPs as targets for drug development in cancer prevention In the past ten years, an increasing number of studies have indicated that most of USPs positively regulate cancer progression, including cell growth and malignancy.
Recently, more inhibitors of USPs have been identified (Table 1). Most of the inhibitors can block more than one USP. Thus, increasing the specificity and effect of the inhibitors should be important in the future development. Herein we discussed how to develop a specific inhibitor of USPs. The development of USP inhibitors has resulted in a range of small molecule inhibitors and has been summarized in previous reviews [104, 105]. Many identified USP inhibitors have been suggested to have paninhibitory activity [104, 105]. For example, compound WP1130 has a broad panenzymatic DUB profile and can directly inhibit USP9x, USP5 and USP14 $[106,107]$. However, this paninhibition may produce unwanted side effects. Designing a drug targeting a specific USP has proven challenging. This is due to the similarity of the conserved catalytic domain of the USP family. Therefore, identifying nonconserved regions is useful for designing specific USP inhibitors. In addition, further research on the interactions between compounds and the USP catalytic site is needed.

Sequence conservation analysis can provide clues for designing a selective inhibitor against a target protein. Using the crystal structure of a target protein, researchers can infer interactions in the catalytic domain to identify and design selective inhibitors. A sequence conservation analysis of USP was performed for this review. USP domain sequences were obtained from the UniProt Consortium [108]. A multiple sequence alignment (MSA) was performed using T-Coffee (http://tcof fee.crg.cat). Next, the MSA was submitted to the Consurf server (http://consurf.tau.ac.il/2016/) to identify conserved and nonconserved sequences. Each residue position was assigned a conservation score from variable (1) to conserved (9). Finally, the conservation score was mapped to the structure of USP7. Conserved and nonconserved regions exist in the USP catalytic domain (Fig. 1). For example, USP7 residue F409 has a high conservation score of 9. Residue F409, when USP7 is in complex with an inhibitor, adopts a conformation that produces a hydrophobic region that can be exploited by an inhibitor [109]. With the absence of crystal structures in complex with an inhibitor for other USP family members, analyzing the catalytic domain sequence remains crucial for designing possible inhibitors.

The sequence conservation analysis of the catalytic domain produced two nonconserved regions, designated Site 1 and Site 2 . These are unique regions that vary between the USP family members and may be used to design a selective compound (Fig. 1a). The side chains of USP7 residues Q297 and Q351 are angled toward the Site 1 region. This allows possible hydrogen bond formation between a compound and USP7. However, the sequence analysis revealed different types of amino acids in these positions for USP family members. For instance, 


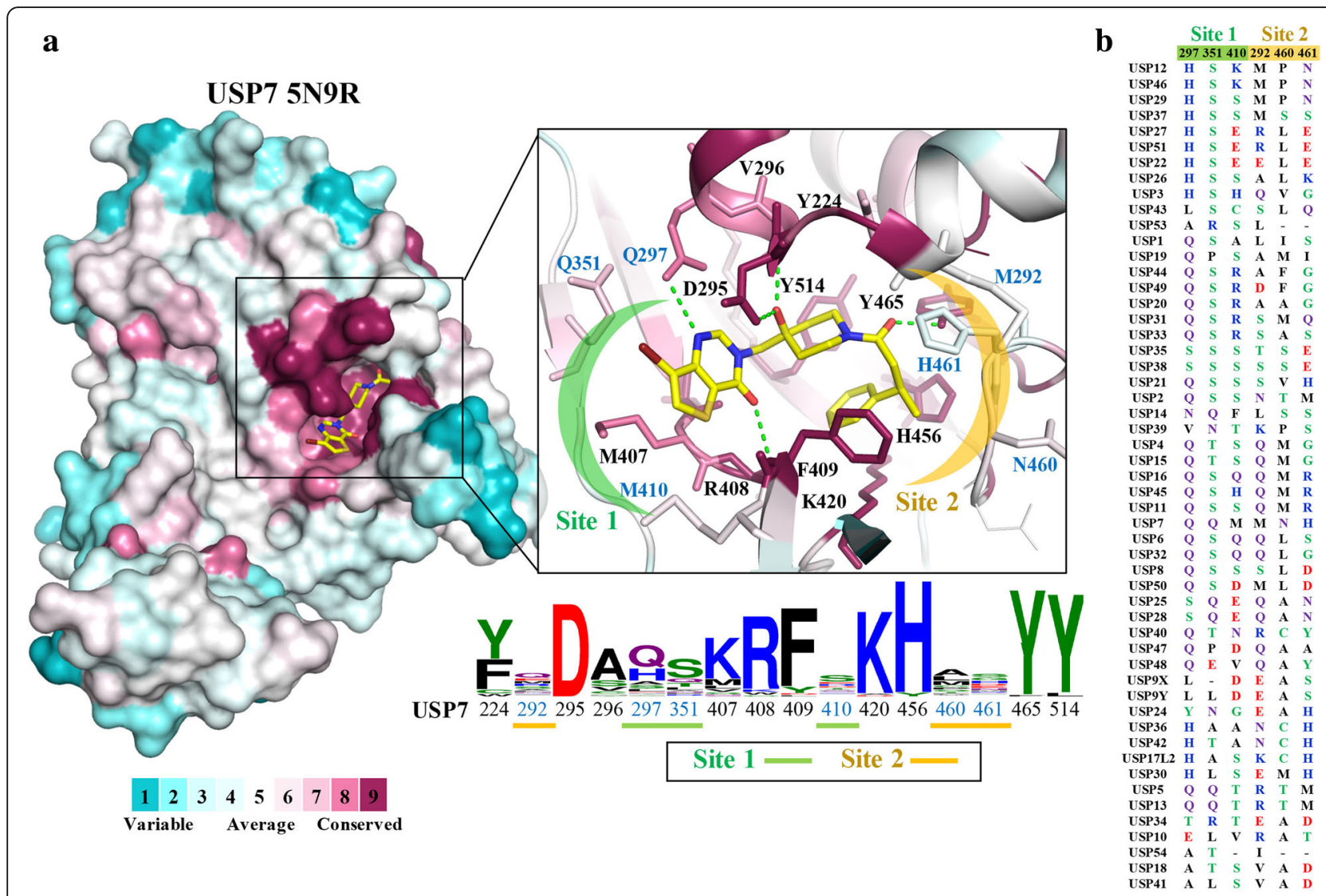

Fig. 1 The USP family of proteins contain conserved and nonconserved catalytic regions. a Conservation score of the USP residue. The structure of USP7 (PDB ID: 5N9R) is used as a reference. Regions are shaded in blue, indicating nonconserved, or red, indicating conserved. The insert shows USP7 catalytic site residues and cocrystal ligand (yellow) as a stick model. The sequence pattern for the USP protein family is shown, with the USP7 sequence as a reference. Sites are highlighted as shown. The green line denotes the hydrogen bond. $\mathbf{b}$ Sequence alignment of Site 1 (green) and Site 2 (yellow). The sequence pattern figure was produced using the weblogo3 server (http://weblogo.threeplusone.com/create.cgi).

residue Q297 of USP7 is replaced by an alanine residue in USP18 and 54 (Fig. 1b). The alanine residue contains a shorter side chain than USP7 residue Q297. Furthermore, the alanine residue would not facilitate a hydrogen bond with its side chain. As a result, the catalytic region at Site 1 may be larger in other USP family members. This suggests that a compound with a larger nonpolar functional group would form additional van der Waals interactions with alanine. Such molecules may be more selective toward USP family members with alanine in this position. Many USP family members contain a serine at the 351 position (Fig. 1b). The serine side chain is shorter than the glutamine residue side chain. USP18 and USP41 contain an alanine and a threonine residue at the USP7 residue Q297 and Q351 position, respectively (Fig. 1b). This would suggest a larger Site 1 region. For example, the analysis suggests that USP18 and USP41 may have a larger Site 1 region. This region can accommodate a larger compound as well as a possible hydrogen bond with the threonine side chain to yield a selective USP18 or USP41 inhibitor. Finally, USP7 residue M410 occupies a region in the periphery of the USP7 catalytic site. Many USP family members contain residues at this position that are negatively charged. The presence of glutamate and aspartic acid residues at this position may form a salt bridge with a compound that has a positively charged functional group to make a specific interaction. Thus, the sequence conservation analysis suggests that a nonconserved pocket can be used to design selective USP inhibitors.

Site 2 is the other identified nonconserved region. This region consists of USP7 residues M292, N460 and H461 (Fig. 1a). According to the reference structure USP7, the side chains of residues at positions 292 and 460 face away from the catalytic region. This suggests that no direct interactions between compounds and the residue side chain occur with this region. However, the residue type at position 461 in USP7 is variable among the USP family (Fig. 1b). The side chain of residue USP7 H461 points inwards toward Site 2. This suggests that interactions at this position can greatly aid in USP selectivity. For example, USP12 contains an asparagine residue at 
this position and can form a hydrogen bond with a compound in this region. Possible hydrogen bond formation is also observed at this position with a serine residue in USP37. USP37 may also have a larger catalytic region at Site 2 due to the shorter side chain of serine. As a result, USP37 may be able to accommodate a compound with a larger moiety at Site 2 . In total, the sequence conservation analysis identified two nonconserved sites. Interactions with the nonconserved sites present the possibility of designing a selective UPS inhibitor.

\section{Conclusion}

Post-translational modification of protein is important for maintaining the physiological function. Dysregulation of protein ubiquitination will induce many diseases, such as cancer. E1/E2/E3-ligases and deubiquitinases regulate protein ubiquitination to control the function and stability of protein. Although many studies have addressed the importance of the USPs in cancer progression, several issues about USPs are still unknown. First, most of the substrates contain more than one deubiquitinases, why are more deubiquitinases needed to regulate the same protein? Second, according many previous studies, a lot of USPs are involved in the DNA damage repair activity, implying USPs may be related to drug resistance during cancer treatment. Therefore, more in-depth studies for clarifying the molecular mechanism are important. Finally, many USPs have been used as the target to develop the inhibitors. How to develop the inhibitors with more effective, low side effect and higher specificity is the most important issue in the future.

\section{Acknowledgements}

We will thank Dr. Wang Shao-An to give the suggestion for the manuscript writing.

\section{Funding}

This work was supported by the grants (106-2320-B-006-065-MY3, 106-2320B-006-020-MY3, and 104-2923-B-038-002-MY3) obtained from the Ministry of Science and Technology, Taiwan.

\section{Availability of data and materials}

Not applicable.

\section{Authors' contributions}

Hung JJ is contribution to conception and design, manuscript writing. Yang $\mathrm{MJ}$ is contribution to data collection, manuscript writing. Hsu KC is contribution to manuscript writing. Lin TE is contribution to data collection. Chang WC is contribution to manuscript writing and editing. All authors read and approved the final manuscript.

Ethics approval and consent to participate

Not applicable.

\section{Consent for publication}

Not applicable.

\section{Competing interests}

The authors declare that they have no competing interests.

\section{Publisher's Note}

Springer Nature remains neutral with regard to jurisdictional claims in published maps and institutional affiliations.

\section{Author details}

'Department of Biotechnology and Bioindustry Sciences, National Cheng Kung University, Tainan 701, Taiwan. ${ }^{2}$ Graduate Institute of Cancer Biology and Drug Discovery, College of Medical Science and Technology, Taipei Medical University, Taipei, Taiwan. ${ }^{3}$ Ph.D. Program for Cancer Molecular Biology and Drug Discovery, College of Medical Science and Technology, Taipei Medical University, Taipei, Taiwan. ${ }^{4}$ Biomedical Commercialization Center, Taipei Medical University, Taipei, Taiwan. ${ }^{5}$ The Ph.D. Program for Neural Regenerative Medicine, Taipei Medical University, Taipei, Taiwan. ${ }^{6}$ Graduate Institute of Medical Sciences, College of Medicine, Taipei Medical University, Taipei, Taiwan.

Received: 20 March 2019 Accepted: 16 April 2019

Published online: 27 May 2019

\section{References}

1. Millar AH, Heazlewood JL, Giglione C, Holdsworth MJ, Bachmair A, Schulze WX. The Scope, Functions, and Dynamics of Posttranslational Protein Modifications. Annu Rev Plant Biol. 2019;29(70):119-51.

2. Vu LD, Gevaert K, De Smet I. Protein Language: Post-Translational Modifications Talking to Each Other. Trends Plant Sci. 2018;23(12):1068-80

3. Scheffner $M$, Nuber $U$, Huibregtse JM. Protein ubiquitination involving an E1-E2-E3 enzyme ubiquitin thioester cascade. Nature. 1995;373(6509):81-3.

4. Swatek KN, Komander D. Ubiquitin modifications. Cell Res. 2016;26(4): 399-422.

5. Haglund K, Dikic I. Ubiquitylation and cell signaling. EMBO J. 2005;24(19): 3353-9.

6. Saeki Y, Kudo T, Sone T, Kikuchi Y, Yokosawa H, Toh-e A, Tanaka K. Lysine 63-linked polyubiquitin chain may serve as a targeting signal for the 265 proteasome. EMBO J. 2009;28(4):359-71.

7. Lecker SH, Goldberg AL, Mitch WE. Protein degradation by the ubiquitinproteasome pathway in normal and disease states. J Am Soc Nephrol. 2006; 17(7):1807-19.

8. Ciechanover A, Kwon YT. Degradation of misfolded proteins in neurodegenerative diseases: therapeutic targets and strategies. Exp Mol Med. 2015;47:e147.

9. Shi D, Grossman SR. Ubiquitin becomes ubiquitous in cancer: emerging roles of ubiquitin ligases and deubiquitinases in tumorigenesis and as therapeutic targets. Cancer Biol Ther. 2010;10(8):737-47.

10. Mevissen TET, Komander D. Mechanisms of Deubiquitinase Specificity and Regulation. Annu Rev Biochem. 2017;86:159-92.

11. Clague MJ, Urbe S, Komander D. Breaking the chains: deubiquitylating enzyme specificity begets function. Nat Rev Mol Cell Biol. 2019.

12. Komander D, Clague MJ, Urbe S. Breaking the chains: structure and function of the deubiquitinases. Nat Rev Mol Cell Biol. 2009;10(8):550-63.

13. Clague MJ, Barsukov I, Coulson JM, Liu H, Rigden DJ, Urbe S. Deubiquitylases from genes to organism. Physiol Rev. 2013;93(3):1289-315.

14. Reyes-Turcu FE, Ventii KH, Wilkinson KD. Regulation and Cellular Roles of Ubiquitin-Specific Deubiquitinating Enzymes. Annual Review of Biochemistry. 2009;78:363-97.

15. Nijman SMB, Luna-Vargas MPA, Velds A, Brummelkamp TR, Dirac AMG, Sixma TK, Bernards R. A genomic and functional inventory of deubiquitinating enzymes. Cell. 2005;123(5):773-86.

16. Shan J, Zhao WH, Gu W. Suppression of Cancer Cell Growth by Promoting Cyclin D1 Degradation. Mol Cell. 2009;36(3):469-76.

17. Gennaro VJ, Stanek TJ, Peck AR, Sun YG, Wang F, Qie S, Knudsen KE, Rui H, Butt T, Diehl JA, McMahon SB. Control of CCND1 ubiquitylation by the catalytic SAGA subunit USP22 is essential for cell cycle progression through G1 in cancer cells. P Natl Acad Sci USA. 2018;115(40):E9298-307.

18. Davis MI, Pragani R, Fox JT, Shen M, Parmar K, Gaudiano EF, Liu L, Tanega C, Mcgee L, Hall MD, McKnight C, Shinn P, Nelson H, Chattopadhyay D, D'Andrea AD, Auld DS, DeLucas L, Li ZY, Boxer MB, Sinneonov A. Small Molecule Inhibition of the Ubiquitin-specific Protease USP2 Accelerates cyclin D1 Degradation and Leads to Cell Cycle Arrest in Colorectal Cancer and Mantle Cell Lymphoma Models. J Biological Chemistry. 2016;291(47): 24628-40. 
19. Zhang C, Lu J, Zhang QW, Zhao W, Guo JH, Liu SL, Wu YL, Jiang B, Gao FH. USP7 promotes cell proliferation through the stabilization of Ki-67 protein in non-small cell lung cancer cells. Int J Biochem Cell B. 2016;79:209-21.

20. Georges A, Marcon E, Greenblatt J, Frappier L. Identification and Characterization of USP7 Targets in Cancer Cells. Sci Rep-Uk. 2018;8.

21. Zhang L, Wang H, Tian L, Li HX. Expression of USP7 and MARCH7 Is Correlated with Poor Prognosis in Epithelial Ovarian Cancer. Tohoku J Exp Med. 2016;239(3):165-75.

22. $\mathrm{Xu} \mathrm{YH,} \mathrm{Lu} \mathrm{S.} \mathrm{Metformin} \mathrm{Inhibits} \mathrm{Esophagus} \mathrm{Cancer} \mathrm{Proliferation} \mathrm{through}$ Upregulation of USP7. Cellular Physiology and Biochemistry. 2013;32(5): $1178-86$.

23. Wang SA, Wang YC, Chuang YP, Huang YH, Su WC, Chang WC, Hung JJ. EGF-mediated inhibition of ubiquitin-specific peptidase 24 expression has a crucial role in tumorigenesis. Oncogene. 2017;36(21):2930-45.

24. Vodermaier HC. APC/C and SCF: Controlling each other and the cell cycle. Curr Biol. 2004;14(18):R787-96.

25. Yang WC, Shih HM. The deubiquitinating enzyme USP37 regulates the oncogenic fusion protein PLZF/RARA stability. Oncogene. 2013;32(43): 5167-75.

26. Das CM, Taylor P, Gireud M, Singh A, Lee D, Fuller G, Ji L, Fangusaro J, Rajaram V, Goldman S, Eberhart C, Gopalakrishnan V. The deubiquitylase USP37 links REST to the control of p27 stability and cell proliferation. Oncogene. 2013;32(13):1691-701.

27. Park JM, Lee JE, Park CM, Kim JH. USP44 Promotes the Tumorigenesis of Prostate Cancer Cells through EZH2 Protein Stabilization. Mol Cells. 2019; 42(1):17-27

28. Nishimura S, Oki E, Ando K, limori M, Nakaji Y, Nakashima $Y$, Saeki H, Oda Y, Maehara Y. High ubiquitin-specific protease 44 expression induces DNA aneuploidy and provides independent prognostic information in gastric cancer. Cancer Med-Us. 2017;6(6):1453-64.

29. Holland AJ, Cleveland DW. The deubiquitinase USP44 is a tumor suppressor that protects against chromosome missegregation. Journal of Clinical Investigation. 2012;122(12):4325-8.

30. Lan XJ, Atanassov BS, Li WQ, Zhang Y, Florens L, Mohan RD, Galardy PJ, Washburn MP, Workman JL, Dent SYR. USP44 Is an Integral Component of $\mathrm{N}-\mathrm{CoR}$ that Contributes to Gene Repression by Deubiquitinating Histone H2B. Cell Rep. 2016;17(9):2382-93.

31. Benassi B, Flavin R, Marchionni L, Zanata S, Pan YF, Chowdhury D, Marani M, Strano S, Muti P, Blandino G, Loda M. MYC Is Activated by USP2a-Mediated Modulation of MicroRNAs in Prostate Cancer. Cancer Discov. 2012;2(3):236-47.

32. Lin ZH, Yang H, Tan C, Li JP, Liu ZJ, Quan Q, Kong SY, Ye JS, Gao BX, Fang DY. USP10 Antagonizes c-Myc Transcriptional Activation through SIRT6 Stabilization to Suppress Tumor Formation. Cell Rep. 2013;5(6):1639-49.

33. Ji M, Shi HR, Xie Y, Zhao Z, Li SS, Chang C, Cheng XH, Li Y. Ubiquitin specific protease 22 promotes cell proliferation and tumor growth of epithelial ovarian cancer through synergy with transforming growth factor beta 1 . Oncology Reports. 2015;33(1):133-40.

34. Liu YL, Jiang SX, Yang YM, Xu H, Liu JL, Wang XS. USP22 Acts as an Oncogene by the Activation of BMI-1-Mediated INK4a/ARF Pathway and Akt Pathway. Cell Biochem Biophys. 2012;62(1):229-35.

35. Ma Y, Fu HL, Wang Z, Huang H, Ni J, Song J, Xia Y, Jin WL, Cui DX. USP22 maintains gastric cancer stem cell stemness and promotes gastric cancer progression by stabilizing BMI1 protein. Oncotarget. 2017;8(20):33329-42.

36. Kim D, Hong A, Park HI, Shin WH, Yoo L, Jeon SJ, Chung KC. Deubiquitinating enzyme USP22 positively regulates c-Myc stability and tumorigenic activity in mammalian and breast cancer cells. J Cell Physiol. 2017;232(12):3664-76.

37. Zhao LJ, Zhang T, Feng XJ, Chang J, Suo FZ, Ma JL, Liu YJ, Liu Y, Zheng YC, Liu HM. USP28 contributes to the proliferation and metastasis of gastric cancer. J Cell Biochem. 2018

38. Weili Z, Zhikun L, Jianmin W, Qingbao T. Knockdown of USP28 enhances the radiosensitivity of esophageal cancer cells via the c-Myc/hypoxiainducible factor-1 alpha pathway. J Cell Biochem. 2019;120(1):201-12.

39. Sun XX, Sears RC, Dai MS. Deubiquitinating c-Myc: USP36 steps up in the nucleolus. Cell Cycle. 2015;14(24):3786-93.

40. Pan J, Deng Q, Jiang C, Wang X, Niu T, Li H, Chen T, Jin J, Pan W, Cai X, Yang X, Lu M, Xiao J, Wang P. USP37 directly deubiquitinates and stabilizes c-Myc in lung cancer. Oncogene. 2015;34(30):3957-67.

41. Bykov VJN, Eriksson SE, Bianchi J, Wiman KG. Targeting mutant p53 for efficient cancer therapy. Nat Rev Cancer. 2018;18(2):89-102.
42. Zhao K, Yang Y, Zhang G, Wang C, Wang D, Wu M, Mei Y. Regulation of the Mdm2-p53 pathway by the ubiquitin E3 ligase MARCH7. Embo Rep. 2018; 19(2):305-19.

43. Brooks CL, Gu W. p53 regulation by ubiquitin. FEBS Lett. 2011;585(18):2803-9.

44. Stevenson LF, Sparks A, Allende-Vega N, Xirodimas DP, Lane DP, Saville MK. The deubiquitinating enzyme USP2a regulates the p53 pathway by targeting Mdm2. EMBO J. 2007;26(4):976-86

45. Mungamuri SK, Qiao RF, Yao S, Manfredi JJ, Gu W, Aaronson SA. USP7 Enforces Heterochromatinization of p53 Target Promoters by Protecting SUV39H1 from MDM2-Mediated Degradation. Cell Rep. 2016;14(11):2528-37.

46. Wang CL, Wang JY, Liu ZY, Ma XM, Wang XW, Jin H, Zhang XP, Fu D, Hou LJ, Lu YC. Ubiquitin-specific protease 2a stabilizes MDM4 and facilitates the p53-mediated intrinsic apoptotic pathway in glioblastoma. Carcinogenesis. 2014;35(7):1500-9.

47. Zhang X, Berger FG, Yang J, Lu X. USP4 inhibits p53 through deubiquitinating and stabilizing ARF-BP1. EMBO J. 2011;30(11):2177-89.

48. Li Z, Hao Q, Luo J, Xiong J, Zhang S, Wang T, Bai L, Wang W, Chen M, Wang W, Gu L, Lv K, Chen J. USP4 inhibits p53 and NF-kappaB through deubiquitinating and stabilizing HDAC2. Oncogene. 2016;35(22):2902-12.

49. Dayal S, Sparks A, Jacob J, Allende-Vega N, Lane DP, Saville MK. Suppression of the deubiquitinating enzyme USP5 causes the accumulation of unanchored polyubiquitin and the activation of p53. J Biol Chem. 2009; 284(8):5030-41.

50. Takayama Kl, Suzuki T, Fujimura T, Takahashi S, Inoue S. Association of USP10 with G3BP2 Inhibits p53 Signaling and Contributes to Poor Outcome in Prostate Cancer. Mol Cancer Res. 2018;16(5):846-56.

51. Sun J, Li TX, Zhao YY, Huang LR, Sun H, Wu H, Jiang XF. USP10 inhibits lung cancer cell growth and invasion by upregulating PTEN. Mol Cell Biochem. 2018:441(1-2):1-7.

52. Zou Q, Jin J, Hu HB, Li HYS, Romano S, Xiao YC, Nakaya M, Zhou XF, Cheng XH, Yang PR, Lozano G, Zhu CM, Watowich SS, Ullrich SE, Sun SC. USP15 stabilizes MDM2 to mediate cancer-cell survival and inhibit antitumor T cell responses. Nat Immunol. 2014;15(6):562-70.

53. Hock AK, Vigneron AM, Carter S, Ludwig RL, Vousden KH. Regulation of p53 stability and function by the deubiquitinating enzyme USP42. EMBO J. 2011; 30(24):4921-30

54. Koster R, Timmer-Bosscha H, Bischoff R, Gietema JA, de Jong S. Disruption of the MDM2-p53 interaction strongly potentiates p53-dependent apoptosis in cisplatin-resistant human testicular carcinoma cells via the Fas/FasL pathway. Cell Death Dis. 2011;2:e148.

55. Potu H, Peterson LF, Pal A, Verhaegen M, Cao J, Talpaz M, Donato NJ. Usp5 links suppression of p53 and FAS levels in melanoma to the BRAF pathway. Oncotarget. 2014;5(14):5559-69.

56. Yuan J, Luo K, Zhang L, Cheville JC, Lou Z. USP10 regulates p53 localization and stability by deubiquitinating p53. Cell. 2010;140(3):384-96.

57. Zhang L, Nemzow L, Chen H, Lubin A, Rong X, Sun Z, Harris TK, Gong F. The deubiquitinating enzyme USP24 is a regulator of the UV damage response. Cell Rep. 2015;10(2):140-7.

58. Weber A, Heinlein M, Dengjel J, Alber C, Singh PK, Hacker G. The deubiquitinase Usp27x stabilizes the $\mathrm{BH}$-only protein Bim and enhances apoptosis. Embo Rep. 2016;17(5):724-38.

59. Liang JR, Martinez A, Lane JD, Mayor U, Clague MJ, Urbe S. USP30 deubiquitylates mitochondrial Parkin substrates and restricts apoptotic cell death. Embo Rep. 2015;16(5):618-27.

60. Wang W, Wang J, Yan H, Zhang K, Liu Y. Upregulation of USP11 promotes epithelialtomesenchymal transition by deubiquitinating Snail in ovarian cancer. Oncol Rep. 2019:41(3):1739-48.

61. Aggarwal K, Massague J. Ubiquitin removal in the TGF-beta pathway. Nat Cell Biol. 2012;14(7):656-7.

62. Jin J, Liu J, Chen C, Liu Z, Jiang C, Chu H, Pan W, Wang X, Zhang L, Li B, Jiang C, Ge X, Xie X, Wang P. The deubiquitinase USP21 maintains the stemness of mouse embryonic stem cells via stabilization of Nanog. Nat Commun. 2016;7:13594.

63. Oh E, Kim JY, Sung D, Cho Y, Lee N, An H, Kim YJ, Cho TM, Seo JH. Inhibition of ubiquitin-specific protease 34 (USP34) induces epithelialmesenchymal transition and promotes stemness in mammary epithelial cells. Cell Signal. 2017;36:230-9.

64. Choi BJ, Park SA, Lee SY, Cha YN, Surh YJ. Hypoxia induces epithelialmesenchymal transition in colorectal cancer cells through ubiquitin-specific protease 47-mediated stabilization of Snail: A potential role of Sox9. Sci Rep. 2017;7(1):15918. 
65. Yang Z, Huo S, Shan Y, Liu H, Xu Y, Yao K, Li X, Zhang X. STAT3 repressed USP7 expression is crucial for colon cancer development. FEBS Lett. 2012; 586(19):3013-7.

66. Wang Z, Yang J, Di J, Cui M, Xing J, Wu F, Wu W, Yang H, Zhang C, Yao Z, Zhang N, Jiang B, Su X. Downregulated USP3 mRNA functions as a competitive endogenous RNA of SMAD4 by sponging miR-224 and promotes metastasis in colorectal cancer. Sci Rep. 2017;7(1):4281.

67. Cheng YC, Shieh SY. Deubiquitinating enzyme USP3 controls CHK1 chromatin association and activation. Proc Natl Acad Sci U S A. 2018; 115(21):5546-51.

68. Pannem RR, Dorn C, Ahlqvist K, Bosserhoff AK, Hellerbrand C, Massoumi R. CYLD controls C-MYC expression through the JNK-dependent signaling pathway in hepatocellular carcinoma. Carcinogenesis. 2014;35(2):461-8.

69. Wertz IE, Dixit VM. Signaling to NF-kappaB: regulation by ubiquitination. Cold Spring Harb Perspect Biol. 2010;2(3):a003350.

70. Sun WJ, Tan XJ, Shi Y, Xu GF, Mao RF, Gu X, Fan YH, Yu Y, Burlingame S, Zhang H, Rednam SP, Lu XB, Zhang T, Fu SB, Cao GW, Qin J, Yang JH. USP11 negatively regulates TNF alpha-induced NF-kappa B activation by targeting on I kappa B alpha. Cell Signal. 2010;22(3):386-94.

71. Yang Z, Xian H, Hu J, Tian S, Qin Y, Wang RF, Cui J. USP18 negatively regulates NF-kappaB signaling by targeting TAK1 and NEMO for deubiquitination through distinct mechanisms. Sci Rep. 2015;5:12738.

72. Tao L, Chen C, Song H, Piccioni M, Shi G, Li B. Deubiquitination and stabilization of IL-33 by USP21. Int J Clin Exp Pathol. 2014;7(8):4930-7.

73. Sun SC. CYLD: a tumor suppressor deubiquitinase regulating NF-kappaB activation and diverse biological processes. Cell Death Differ. 2010;17(1):25-34.

74. Xiao N, Li H, Luo J, Wang R, Chen H, Chen J, Wang P. Ubiquitin-specific protease 4 (USP4) targets TRAF2 and TRAF6 for deubiquitination and inhibits TNFalpha-induced cancer cell migration. Biochem J. 2012;441(3):979-86.

75. Wang YC, Wu YS, Hung CY, Wang SA, Young MJ, Hsu TI, Hung JJ. USP24 induces IL-6 in tumor-associated microenvironment by stabilizing p300 and beta-TrCP and promotes cancer malignancy. Nat Commun. 2018;9.

76. Liu C, Wang L, Chen W, Zhao S, Yin C, Lin Y, Jiang A, Zhang P. USP35 activated by miR let-7a inhibits cell proliferation and NF-kappaB activation through stabilization of ABIN-2. Oncotarget. 2015;6(29):27891-906.

77. Xie F, Ling L, van Dam H, Zhou FF, Zhang L. TGF-beta signaling in cancer metastasis. Acta Bioch Bioph Sin. 2018;50(1):121-32.

78. lyengar PV. Regulation of Ubiquitin Enzymes in the TGF-beta Pathway. International Journal of Molecular Sciences. 2017;18(4).

79. Liu WT, Huang KY, Lu MC, Huang HL, Chen CY, Cheng YL, Yu HC, Liu SQ, Lai NS, Huang HB. TGF-beta upregulates the translation of USP15 via the PI3K/AKT pathway to promote p53 stability. Oncogene. 2017; 36(19):2715-23.

80. Eichhorn PJA, Rodon L, Gonzalez-Junca A, Dirac A, Gili M, Martinez-Saez E, Aura C, Barba I, Peg V, Prat A, Cuartas I, Jimenez J, Garcia-Dorado D, Sahuquillo J, Bernards R, Baselga J, Seoane J. USP15 stabilizes TGF-beta receptor I and promotes oncogenesis through the activation of TGF-beta signaling in glioblastoma. Nat Med. 2012;18(3):429-U192.

81. Zhang L, Zhou FF, Drabsch Y, Gao R, Snaar-Jagalska BE, Mickanin C, Huang HZ, Sheppard KA, Porter JA, Lu CX, ten Dijke P. USP4 is regulated by AKT phosphorylation and directly deubiquitylates TGF-beta type I receptor. Nat Cell Biol. 2012;14(7):717-26.

82. Zhu J, Luo Z, Pan Y, Zheng W, Li W, Zhang Z, Xiong P, Xu D, Du M, Wang B, Yu J, Zhang J, Liu J. H19/miR-148a/USP4 axis facilitates liver fibrosis by enhancing TGF-beta signaling in both hepatic stellate cells and hepatocytes. J Cell Physiol. 2019;234(6):9698-710.

83. Wu Y, Yu X, Yi X, Wu K, Dwabe S, Atefi M, Elshimali Y, Kemp KT 2nd, Bhat K, Haro J, Sarkissyan M, Vadgama JV. Aberrant Phosphorylation of SMAD4 Thr277-Mediated USP9x-SMAD4 Interaction by Free Fatty Acids Promotes Breast Cancer Metastasis. Cancer Res. 2017;77(6):1383-94.

84. Kim SY, Baek KH. TGF-beta signaling pathway mediated by deubiquitinating enzymes. Cell Mol Life Sci. 2019;76(4):653-65.

85. Zhan T, Rindtorff N, Boutros M. Wnt signaling in cancer. Oncogene. 2017; 36(11):1461-73.

86. Yun SI, Kim HH, Yoon JH, Park WS, Hahn MJ, Kim HC, Chung CH, Kim KK. Ubiquitin specific protease 4 positively regulates the WNT/beta-catenin signaling in colorectal cancer. Mol Oncol. 2015;9(9):1834-51.

87. Premarathne S, Murtaza M, Matigian N, Jolly LA, Wood SA. Loss of Usp9x disrupts cell adhesion, and components of the Wnt and Notch signaling pathways in neural progenitors. Sci Rep. 2017;7(1):8109.
88. Jung H, Kim BG, Han WH, Lee JH, Cho JY, Park WS, Maurice MM, Han JK, Lee MJ, Finley D, Jho EH. Deubiquitination of Dishevelled by Usp14 is required for Wht signaling. Oncogenesis. 2013;2:e64.

89. Guo Q, Jin Z, Yuan Y, Liu R, Xu T, Wei H, Xu X, He S, Chen S, Shi Z, Hou W, Hua B. New Mechanisms of Tumor-Associated Macrophages on Promoting Tumor Progression: Recent Research Advances and Potential Targets for Tumor Immunotherapy. J Immunol Res. 2016;2016:9720912.

90. Ngambenjawong C, Gustafson HH, Pun SH. Progress in tumor-associated macrophage (TAM)-targeted therapeutics. Adv Drug Deliv Rev. 2017;114:206-21.

91. Chanmee T, Ontong P, Konno K, Itano N. Tumor-Associated Macrophages as Major Players in the Tumor Microenvironment. Cancers. 2014;6(3):1670-90.

92. Chen J, Dexheimer TS, Ai Y, Liang Q, Villamil MA, Inglese J, Maloney DJ, Jadhav A, Simeonov A, Zhuang Z. Selective and cell-active inhibitors of the USP1/ UAF1 deubiquitinase complex reverse cisplatin resistance in nonsmall cell lung cancer cells. Chem Biol. 2011:18(11):1390-400.

93. Nakajima S, Lan L, Wei L, Hsieh CL, Rapic-Otrin V, Yasui A, Levine AS. Ubiquitin-Specific Protease 5 Is Required for the Efficient Repair of DNA Double-Strand Breaks. Plos One. 2014;9(1).

94. Deng TG, Yan GB, Song X, Xie L, Zhou Y, Li JL, Hu XX, Li Z, Hu J, Zhang YB, Zhang $H$, Sun Y, Feng PF, Wei D, Hu B, Liu J, Tan WH, Ye M. Deubiquitylation and stabilization of p21 by USP11 is critical for cell-cycle progression and DNA damage responses. P Natl Acad Sci USA. 2018;115(18): 4678-83.

95. Byun S, Lee SY, Lee J, Jeong CH, Farrand L, Lim S, Reddy K, Kim JY, Lee MH, Lee HJ, Bode AM, Won LK, Dong Z. USP8 is a novel target for overcoming gefitinib resistance in lung cancer. Clin Cancer Res. 2013;19(14):3894-904.

96. Fu Y, Ma G, LiU G, Li B, Li H, Hao X, Liu L. USP14 as a novel prognostic marker promotes cisplatin resistance via Akt/ERK signaling pathways in gastric cancer. Cancer Med. 2018;7(11):5577-88.

97. Liu JP, Kruswick A, Dang H, Tran AD, Kwon SM, Wang XW, Oberdoerffer P. Ubiquitin-specific protease 21 stabilizes BRCA2 to control DNA repair and tumor growth. Nat Commun. 2017:8.

98. Zhang HJ, Han B, Lu HL, Zhao YB, Chen XS, Meng QW, Cao MR, Cai L, Hu J. USP22 promotes resistance to EGFR-TKIs by preventing ubiquitinationmediated EGFR degradation in EGFR-mutant lung adenocarcinoma. Cancer Letters. 2018:433:186-98.

99. Melo-Cardenas J, Xu YM, Wei JC, Tan C, Kong SY, Gao BX, Montauti E, Kirsammer G, Licht JD, YU J, Ji P, Crispino JD, Fang DY. USP22 deficiency leads to myeloid leukemia upon oncogenic Kras activation through a PU.1dependent mechanism. Blood. 2018;132(4):423-34.

100. Wang A, Ning Z, Lu C, Gao W, Liang JX, Yan Q, Tan G, Liu JW. USP22 Induces Cisplatin Resistance in Lung Adenocarcinoma by Regulating gamma H2AX-Mediated DNA Damage Repair and Ku70/Bax-Mediated Apoptosis. Front Pharmacol. 2017;8.

101. Zhang J, Luo N, Tian Y, Li JZ, Yang XZ, Yin HM, Xiao CS, Sheng J, Li Y, Tang B, Li R. USP22 knockdown enhanced chemosensitivity of hepatocellular carcinoma cells to 5-Fu by up-regulation of Smad4 and suppression of Akt. Oncotarget. 2017;8(15):24728-40.

102. Oh E, Kim JY, Sung D, Cho Y, Lee N, An H, Kim YJ, Cho TM, Seo JH. Inhibition of ubiquitin-specific protease 34 (USP34) induces epithelialmesenchymal transition and promotes sternness in mammary epithelial cells. Cell Signal. 2017;36:230-9.

103. Typas D, Luijsterburg MS, Wiegant WW, Diakatou M, Helfricht A, Thijssen PE, de Broek BV, Mullenders LH, van Attikum H. The de-ubiquitylating enzymes USP26 and USP37 regulate homologous recombination by counteracting RAP80. Nucleic Acids Research. 2015;43(14):6919-33.

104. Yuan T, Yan FJ, Ying MD, Cao J, He QJ, Zhu H, Yang B. Inhibition of Ubiquitin-Specific Proteases as a Novel Anticancer Therapeutic Strategy. Front Pharmacol. 2018;9.

105. Patel K, Ahmed ZSO, Huang XM, Yang QQ, Ekinci E, Neslund-Dudas CM, Mitra B, Elnady FAEM, Ahn YH, Yang HJ, Liu JB, Dou QP. Discovering proteasomal deubiquitinating enzyme inhibitors for cancer therapy: lessons from rational design, nature and old drug reposition. Future Med Chem. 2018;10(17):2087-108.

106. Kapuria V, Peterson LF, Fang D, Bornmann WG, Talpaz M, Donato NJ. Deubiquitinase Inhibition by Small-Molecule WP1130 Triggers Aggresome Formation and Tumor Cell Apoptosis. Cancer Research. 2010;70(22):9265-76.

107. Sun HS, Kapuria V, Peterson LF, Fang DX, Bornmann WG, Bartholomeusz G, Talpaz M, Donato NJ. Bcr-Abl ubiquitination and Usp9x inhibition block kinase signaling and promote CML cell apoptosis. Blood. 2011; 117(11):3151-62. 
108. UniProt C. UniProt: a worldwide hub of protein knowledge. Nucleic Acids Res. 2019:47(D1):D506-15.

109. Gavory G, O'Dowd CR, Helm MD, Flasz J, Arkoudis E, Dossang A, Hughes C, Cassidy E, McClelland K, Odrzywol E, Page N, Barker O, Miel H, Harrison T. Discovery and characterization of highly potent and selective allosteric USP7 inhibitors. Nat Chem Biol. 2018;14(2):118-+.

110. Williams SA, Maecker HL, French DM, Liu JF, Gregg A, Silverstein LB, Cao TC, Carano RAD, Dixit VM. USP1 Deubiquitinates ID Proteins to Preserve a Mesenchymal Stem Cell Program in Osteosarcoma. Cell. 2011;146(6):917-29.

111. Mistry H, Hsieh G, Buhrlage SJ, Huang M, Park E, Cuny GD, Galinsky I, Stone RM, Gray NS, D'Andrea AD, Parmar K. Small-Molecule Inhibitors of USP1 Target ID1 Degradation in Leukemic Cells. Mol Cancer Ther. 2013;12(12):2651-62.

112. Liang Q, Dexheimer TS, Zhang P, Rosenthal AS, Villamil MA, You CJ, Zhang QT, Chen JJ, Ott CA, Sun HM, Luci DK, Yuan BF, Simeonov A, Jadhav A, Xiao H, Wang YS, Maloney DJ, Zhuang ZH. A selective USP1-UAF1 inhibitor links deubiquitination to DNA damage responses. Nat Chem Biol. 2014;10(4):298-+.

113. McClurg UL, Robson CN. Deubiquitinating enzymes as oncotargets. Oncotarget. 2015;6(12):9657-68.

114. Altun M, Kramer HB, Willems LI, McDermott IL, Leach CA, Goldenberg SJ, Kumar KGS, Konietzny R, Fischer R, Kogan E, Mackeen MM, McGouran J, Khoronenkova SV, Parsons JL, Dianov GL, Nicholson B, Kessler BM. ActivityBased Chemical Proteomics Accelerates Inhibitor Development for Deubiquitylating Enzymes. Chem Biol. 2011;18(11):1401-12.

115. He X, Li Y, Li C, Liu LJ, Zhang XD, Liu Y, Shu HB. USP2a negatively regulates IL-1-and virus-induced NF-B activation by deubiquitinating TRAF6. J Mol Cell Biol. 2013;5(1):39-47.

116. Tao BB, He H, Shi XH, Wang CL, Li WQ, Li B, Dong Y, Hu GH, Hou L, Luo C, Chen $J X$, Chen HR, Yu YH, Sun QF, Lu YC. Up-regulation of USP2a and FASN in gliomas correlates strongly with glioma grade. J Clin Neurosci. 2013;20(5):717-20.

117. Aleo E, Henderson CJ, Fontanini A, Solazzo B, Brancolini C. Identification of new compounds that trigger apoptosome-independent caspase activation and apoptosis. Cancer research. 2006;66(18):9235-44.

118. Issaenko OA, Amerik AY. Chalcone-based small-molecule inhibitors attenuate malignant phenotype via targeting deubiquitinating enzymes Cell Cycle. 2012;11(9):1804-17.

119. Graner E, Tang D, Rossi S, Baron A, Migita T, Weinstein L, Lechpammer M, Huesken D, Zimmermann J, Signoretti S, Loda M. The isopeptidase USP2a regulates the stability of fatty acid synthase in prostate cancer. Cancer Cell. 2004:5(3):253-61.

120. Altmann E, Aichholz R, Betschart C, Buhl T, Green J, Irie O, Teno N, Lattmann R, Tintelnot-Blomley M, Missbach M. 2-cyano-pyrimidines: A new chemotype for inhibitors of the cysteine protease cathepsin K. J Med Chem. 2007:50(4):591-4.

121. D'Arcy P, Wang X, Linder S. Deubiquitinase inhibition as a cancer therapeutic strategy. Pharmacol Therapeut. 2015;147:32-54.

122. Allende-Vega N, Sparks A, Lane DP, Saville MK. MdmX is a substrate for the deubiquitinating enzyme USP2a. Oncogene. 2010;29(3):432-41.

123. Nicassio F, Corrado N, Vissers JHA, Areces LB, Bergink S, Marteijn JA, Geverts B, Houtsmuller AB, Vermeulen W, Di Fiore PP, Citterio E. Human USP3 is a chromatin modifier required for $S$ phase progression and genome stability. Curr Biol. 2007;17(22):1972-7.

124. Raychaudhuri P. USP3 controls BRCA1 "foci". Cell Cycle 13(2):183-183, 2014

125. Sharma N, Zhu QZ, Wani G, He JS, Wang QE, Wani AA. USP3 counteracts RNF168 via deubiquitinating $\mathrm{H} 2 \mathrm{~A}$ and gamma $\mathrm{H} 2 \mathrm{AX}$ at lysine 13 and 15. Cell Cycle. 2014;13(1):106-14.

126. Fan YH, Yu Y, Mao RF, Tan XJ, Xu GF, Zhang H, Lu XB, Fu SB, Yang J. USP4 targets TAK1 to downregulate TNF alpha-induced NF-kappa B activation. Cell Death Differ. 2011;18(10):1547-60.

127. Okada K, Ye YQ, Taniguchi K, Yoshida A, Akiyama T, Yoshioka Y, Onose J, Koshino H, Takahashi S, Yajima A, Abe N, Yajima S. Vialinin A is a ubiquitinspecific peptidase inhibitor. Bioorganic \& medicinal chemistry letters. 2013; 23(15):4328-31.

128. Xiao N, Li H, Luo J, Wang R, Chen HQ, Chen JQ, Wang P. Ubiquitin-specific protease 4 (USP4) targets TRAF2 and TRAF6 for deubiquitination and inhibits TNF alpha-induced cancer cell migration. Biochem J. 2012;441:979-86.

129. Izaguirre DI, Zhu W, Hai T, Cheung HC, Krahe R, Cote GJ. PTBP1-Dependent Regulation of USP5 Alternative RNA Splicing Plays a Role in Glioblastoma Tumorigenesis. Mol Carcinogen. 2012;51(11):895-906.

130. Bartholomeusz GA, Talpaz M, Kapuria V, Kong LY, Wang S, Estrov Z, Priebe W, Wu J, Donato NJ. Activation of a novel Bcr/Abl destruction pathway by
WP1130 induces apoptosis of chronic myelogenous leukemia cells. Blood. 2007;109(8):3470-8.

131. Kapuria V, Levitzki A, Bornmann WG, Maxwell D, Priebe W, Sorenson RJ, Showalter HD, Talpaz M, Donato NJ. A novel small molecule deubiquitinase inhibitor blocks Jak2 signaling through Jak2 ubiquitination. Cellular signalling. 2011;23(12):2076-85.

132. Perry JW, Ahmed M, Chang KO, Donato NJ, Showalter HD, Wobus CE. Antiviral activity of a small molecule deubiquitinase inhibitor occurs via induction of the unfolded protein response. PLoS pathogens. 2012;8(7): e1002783.

133. Pringle LM, Young R, Quick L, Riquelme DN, Oliveira AM, May MJ, Chou MM Atypical mechanism of NF-kappa B activation by TRE17/ubiquitin-specific protease 6 (USP6) oncogene and its requirement in tumorigenesis. Oncogene. 2012;31(30):3525-35.

134. Colland F, Formstecher E, Jacq X, Reverdy C, Planquette C, Conrath S, Trouplin V, Bianchi J, Aushev VN, Camonis J, Calabrese A, Borg-Capra C, Sippl W, Collura V, Boissy G, Rain JC, Guedat P, Delansorne R, Daviet L. Small-molecule inhibitor of USP7/HAUSP ubiquitin protease stabilizes and activates p53 in cells. Mol Cancer Ther. 2009;8(8):2286-95.

135. Reverdy C, Conrath S, Lopez R, Planquette C, Atmanene C, Collura V, Harpon J, Battaglia V, Vivat V, Sippl W, Colland F. Discovery of Specific Inhibitors of Human USP7/HAUSP Deubiquitinating Enzyme. Chem Biol. 2012;19(4):467-77.

136. Chauhan D, Tian Z, Nicholson B, Kumar KGS, Zhou B, Carrasco R, McDermott JL, Leach CA, Fulcinniti M, Kodrasov MP, Weinstock J, Kingsbury WD, Hideshima T, Shah PK, Minvielle S, Altun M, Kessler BM, Orlowski R, Richardson P, Munshi N, Anderson KC. A Small Molecule Inhibitor of Ubiquitin-Specific Protease-7 Induces Apoptosis in Multiple Myeloma Cells and Overcomes Bortezomib Resistance. Cancer Cell. 2012;22(3):345-58.

137. Weinstock J, Wu J, Cao P, Kingsbury WD, McDermott JL, Kodrasov MP, McKelvey DM, Suresh Kumar KG, Goldenberg SJ, Mattern MR, Nicholson B. Selective Dual Inhibitors of the Cancer-Related Deubiquitylating Proteases USP7 and USP47. ACS medicinal chemistry letters. 2012;3(10):789-92.

138. Kessler BM. Selective and reversible inhibitors of ubiquitin-specific protease 7: a patent evaluation (WO2013030218). Expert Opin Ther Pat. 2014;24(5):597-602.

139. Weinstock J, Wu J, Cao P, Kingsbury WD, McDermott JL, Kodrasov MP, McKelvey DM, Kumar KGS, Goldenberg SJ, Mattern MR, Nicholson B. Selective Dual Inhibitors of the Cancer-Related Deubiquitylating Proteases USP7 and USP47. Acs Med Chem Lett. 2012;3(10):789-92.

140. Sacco JJ, Coulson JM, Clague MJ, Urbe S. Emerging Roles of Deubiquitinases in Cancer-Associated Pathways. lubmb Life. 2010;62(2):140-57.

141. Li MY, Chen DL, Shiloh A, Luo JY, Nikolaev AY, Qin J, Gu W. Deubiquitination of $\mathrm{p} 53$ by HAUSP is an important pathway for $\mathrm{p} 53$ stabilization. Nature. 2002;416(6881):648-53.

142. van der Horst $A$, de Vries-Smits AMM, Brenkman $A B$, van Triest $M H$, van den Broek N, Colland F, Maurice MM, Burgering BMT. FOXO4 transcriptional activity is regulated by monoubiquitination and USP7/HAUSP. Nat Cell Biol. 2006;8(10):1064-U1040.

143. Song MS, Salmena L, Carracedo A, Egia A, Lo-Coco F, Teruya-Feldstein J Pandolfi PP. The deubiquitinylation and localization of PTEN are regulated by a HAUSP-PML network. Nature. 2008:455(7214):813-U811.

144. Karni-Schmidt O, Lokshin M, Prives C. The Roles of MDM2 and MDMX in Cancer. Annu Rev Pathol-Mech. 2016;11:617-44.

145. Li MY, Brooks CL, Kon N, Gu W. A dynamic role of HAUSP in the p53-Mdm2 pathway. Mol Cell. 2004;13(6):879-86.

146. Trotman LC, Wang XJ, Alimonti A, Chen ZB, Teruya-Feldstein J, Yang HJ, Pavletich NP, Carver BS, Cordon-Cardo C, Erdjument-Bromage H, Tempst P, Chi SG, Kim HJ, Misteli T, Jiang XJ, Pandolfi PP. Ubiquitination regulates PTEN nuclear import and tumor suppression. Cell. 2007;128(1):141-56.

147. Berlin I, Higginbotham KM, Dise RS, Sierra MI, Nash PD. The Deubiquitinating Enzyme USP8 Promotes Trafficking and Degradation of the Chemokine Receptor 4 at the Sorting Endosome. Journal of Biological Chemistry. 2010;285(48):37895-908.

148. Panner A, Crane CA, Weng CJ, Feletti A, Fang S, Parsa AT, Pieper RO. Ubiquitin-Specific Protease 8 Links the PTEN-Akt-AIP4 Pathway to the Control of FLIPS Stability and TRAIL Sensitivity in Glioblastoma Multiforme. Cancer Research. 2010;70(12):5046-53.

149. Colombo M, Vallese S, Peretto I, Jaca X, Rain JC, Colland F, Guedat P. Synthesis and Biological Evaluation of 9-Oxo-9H-indeno[1,2-b]pyrazine-2,3dicarbonitrile Analogues as Potential Inhibitors of Deubiquitinating Enzymes. Chemmedchem. 2010;5(4):552-8. 
150. Soares L, Seroogy C, Skrenta H, Anandasabapathy N, Lovelace P, Chung CD, Engleman $\mathrm{E}$, Fathman CG. Two isoforms of otubain 1 regulate $T$ cell anergy via GRAIL. Nat Immunol. 2004;5(1):45-54.

151. Dupont S, Mamidi A, Cordenonsi M, Montagner M, Zacchigna L, Adorno M, Martello G, Stinchfield MJ, Soligo S, Morsut L, Inui M, Moro S, Modena N, Argenton F, Newfeld SJ, Piccolo S. FAM/USP9x, a Deubiquitinating Enzyme Essential for TGF beta Signaling, Controls Smad4 Monoubiquitination. Cell. 2009;136(1):123-35.

152. Schwickart M, Huang XD, Lill JR, Liu JF, Ferrando R, French DM, Maecker $H$, O'Rourke K, Bazan F, Eastham-Anderson J, Yue P, Dornan D, Huang DCS, Dixit VM. Deubiquitinase USP9X stabilizes MCL1 and promotes tumour cell survival. Nature. 2010;463(7277):103-U114.

153. Cox JL, Wilder PJ, Gilmore JM, Wuebben EL, Washburn MP, Rizzino A. The SOX2-Interactome in Brain Cancer Cells Identifies the Requirement of MSI2 and USP9X for the Growth of Brain Tumor Cells. Plos One. 2013;8(5)

154. Peng J, Hu Q, Liu WP, He XL, Cui L, Chen XL, Yang M, Liu HQ, Wei W, Liu SL, Wang H. USP9X expression correlates with tumor progression and poor prognosis in esophageal squamous cell carcinoma. Diagn Pathol. 2013;8.

155. Sun C, Sklaetsky H, Birren B, Devon K, Tang ZL, Silber S, Oates R, Page DC. An azoospermic man with a de novo point mutation in the $Y$-chromosomal gene USP9Y. Nat Genet. 1999;23(4):429-32.

156. Zeng Z, Wu HX, Zhan N, Huang YB, Wang ZS, Yang GF, Wang P, Fu GH. Prognostic significance of USP10 as a tumor-associated marker in gastric carcinoma. Tumor Biol. 2014;35(4):3845-53.

157. Liu JL, Xia HG, Kim M, Xu LH, Li Y, Zhang LH, Cai Y, Norberg HV, Zhang T, Furuya T, Jin MZ, Zhu ZM, Wang HC, Yu J, Li YX, Hao Y, Choi A, Ke HM, Ma DW, Yuan JY. Beclin1 Controls the Levels of p53 by Regulating the Deubiquitination Activity of USP10 and USP13. Cell. 2011;147(1):223-34.

158. Weisberg EL, Schauer NJ, Yang J, Lamberto I, Doherty L, Bhatt S, Nonami A, Meng CC, Letai A, Wright R, Tiv H, Gokhale PC, Ritorto MS, De Cesare V, Trost M, Christodoulou A, Christie A, Weinstock DM, Adamia S, Stone R, Chauhan D, Anderson KC, Seo HS, Dhe-Paganon S, Sattler M, Gray NS, Griffin JD, Buhrlage SJ. Inhibition of USP10 induces degradation of oncogenic FLT3. Nat Chem Biol. 2017;13(12):1207-+.

159. Al-Salihi MA, Herhaus L, Macartney T, Sapkota GP. USP11 augments TGF beta signalling by deubiquitylating ALK5. Open Biol. 2012;2.

160. Burkhart RA, Peng Y, Norris ZA, Tholey RM, Talbott VA, Liang Q, Ai YX, Miller K, Lal S, Cozzitorto JA, Witkiewicz AK, Yeo CJ, Gehrmann M, Napper A, Winter JM, Sawicki JA, Zhuang Z, Brody JR. Mitoxantrone Targets Human Ubiquitin-Specific Peptidase 11 (USP11) and Is a Potent Inhibitor of Pancreatic Cancer Cell Survival. Mol Cancer Res. 2013;11(8):901-11.

161. Wei RB, Liu XD, Yu WX, Yang TS, Cai WP, Liu JJ, Huang X, Xu GT, Zhao SL, Yang JH, Liu SF. Deubiquitinases in cancer. Oncotarget. 2015;6(15):12872-89.

162. Kee Y, Yang KL, Cohn MA, Haas W, Gygi SP, D'Andrea AD. WDR20 Regulates Activity of the USP12 center dot UAF1 Deubiquitinating Enzyme Complex. Journal of Biological Chemistry. 2010;285(15):11252-7.

163. Burska UL, Harle VJ, Coffey K, Darby S, Ramsey H, O'Neill D, Logan IR, Gaughan L, Robson CN. Deubiquitinating Enzyme Usp12 Is a Novel Coactivator of the Androgen Receptor. Journal of Biological Chemistry. 2013; 288(45):32641-50.

164. McClurg UL, Summerscales EE, Harle VJ, Gaughan L, Robson CN. Deubiquitinating enzyme Usp12 regulates the interaction between the androgen receptor and the Akt pathway. Oncotarget. 2014;5(16):7081-92.

165. Zhang SZ, Zhang MY, Jing Y, Yin X, Ma PF, Zhang ZF, Wang XJ, Di W, Zhuang GL. Deubiquitinase USP13 dictates MCL1 stability and sensitivity to BH3 mimetic inhibitors. Nat Commun. 2018;9.

166. Pesce E, Sondo E, Ferrera L, Tomati V, Caci E, Scudieri P, Musante I, Renda M, Baatallah N, Servel N, Hinzpeter A, di Bernardo D, Pedemonte N, Galietta LV. The Autophagy Inhibitor Spautin-1 Antagonizes Rescue of Mutant CFTR Through an Autophagy-Independent and USP13-Mediated Mechanism. Front Pharmacol. 2018;9.

167. Zhang YH, Zhou CJ, Zhou ZR, Song AX, Hu HY. Domain Analysis Reveals That a Deubiquitinating Enzyme USP13 Performs Non-Activating Catalysis for Lys63-Linked Polyubiquitin. Plos One. 2011;6(12).

168. Tian Z, D'Arcy P, Wang X, Ray A, Tai YT, Hu YG, Carrasco RD, Richardson P, Linder S, Chauhan D, Anderson KC. A novel small molecule inhibitor of deubiquitylating enzyme USP14 and UCHL5 induces apoptosis in multiple myeloma and overcomes bortezomib resistance. Blood. 2014;123(5):706-16.

169. Wu N, Liu C, Bai C, Han YP, Cho WCS, Li Q. Over-Expression of Deubiquitinating Enzyme USP14 in Lung Adenocarcinoma Promotes
Proliferation through the Accumulation of beta-Catenin. International Journal of Molecular Sciences. 2013;14(6):10749-60.

170. Lee B-H, Lee MJ, Park S, Oh D-C, Elsasser S, Chen P-C, Gartner C, Dimova N, Hanna J, Gygi SP, Wilson SM, King RW, Finley D. Enhancement of proteasome activity by a small-molecule inhibitor of USP14. Nature. 2010; 467:179.

171. D'Arcy P, Brnjic S, Olofsson MH, Fryknas M, Lindsten K, De Cesare M, Perego $P$, Sadeghi B, Hassan M, Larsson R, Linder S. Inhibition of proteasome deubiquitinating activity as a new cancer therapy. Nature medicine. 2011; 17(12):1636-40.

172. Zhou B, Zuo Y, Li B, Wang H, Liu H, Wang X, Qiu X, Hu Y, Wen S, Du J, Bu X. Deubiquitinase inhibition of 195 regulatory particles by 4-arylidene curcumin analog AC17 causes NF-kappaB inhibition and p53 reactivation in human lung cancer cells. Molecular cancer therapeutics. 2013;12(8):1381-92.

173. Finley D. Recognition and Processing of Ubiquitin-Protein Conjugates by the Proteasome. Annual review of biochemistry. 2009;78:477-513.

174. Slavica L, Nurkkala-Karlsson M, Karlson T, Ingelsten M, Nystrom J, Eriksson K. Indoleamine 2,3-dioxygenase expression and functional activity in dendritic cells exposed to cholera toxin. Scandinavian journal of immunology. 2012; 76(2):113-22.

175. Qiu GZ, Sun W, Jin MZ, Lin J, Lu PG, Jin WL. The bad seed gardener: Deubiquitinases in the cancer stem-cell signaling network and therapeutic resistance. Pharmacol Therapeut. 2017;172:127-38.

176. Eichhorn PJ, Rodon L, Gonzalez-Junca A, Baselga J, Seoane J. USP15 stabilizes the TGF-beta receptor I and promotes oncogenesis through the activation of the TGF-beta signal in glioblastoma. Cancer Research. 2012;72.

177. Inui M, Manfrin A, Mamidi A, Martello G, Morsut L, Soligo S, Enzo E, Moro S, Polo S, Dupont S, Cordenonsi M, Piccolo S. USP15 is a deubiquitylating enzyme for receptor-activated SMADs. Nat Cell Biol. 2011;13(11):1368-U1187.

178. Baker RT, Wang XW, Woollatt E, White JA, Sutherland GR. Identification, functional characterization, and chromosomal localization of USP15, a novel human ubiquitin-specific protease related to the UNP oncoprotein, and a systematic nomenclature for human ubiquitin-specific proteases. Genomics. 1999:59(3):264-74

179. Villeneuve NF, Tian W, Wu TD, Sun Z, Lau A, Chapman E, Fang DY, Zhang DD. USP15 Negatively Regulates Nr12 through Deubiquitination of Keap1. Mol Cell. 2013;51(1):68-79.

180. Gelsi-Boyer V, Trouplin V, Adelaide J, Aceto N, Remy V, Pinson S, Houdayer C, Arnoulet C, Sainty D, Bentires-Alj M, Olschwang S, Vey N, Mozziconacci MJ, Birnbaum D, Chaffanet M. Genome profiling of chronic myelomonocytic leukemia: frequent alterations of RAS and RUNX1 genes. Bmc Cancer. 2008;8.

181. Ernst A, Avvakumov G, Tong JF, Fan YH, Zhao YL, Alberts P, Persaud A, Walker JR, Neculai AM, Neculai D, Vorobyov A, Garg P, Beatty L, Chan PK, Juang YC, Landry MC, Yeh C, Zeqiraj E, Karamboulas K, Allali-Hassani A, Vedadi M, Tyers M, Moffat J, Sicheri F, Pelletier L, Durocher D, Raught B, Rotin D, Yang JH, Moran MF, Dhe-Paganon S, Sidhu SS. A Strategy for Modulation of Enzymes in the Ubiquitin System. Science. 2013;339(6119):590-5.

182. Joo HY, Zhai L, Yang CY, Nie SY, Erdjument-Bromage H, Tempst P, Chang $\mathrm{CB}$, Wang HB. Regulation of cell cycle progression and gene expression by H2A deubiquitination. Nature. 2007:449(7165):1068-U1069.

183. Zhang Z, Yang HR, Wang HB. The Histone H2A Deubiquitinase USP16 Interacts with HERC2 and Fine-tunes Cellular Response to DNA Damage. Journal of Biological Chemistry. 2014:289(47).

184. de la Vega M, Kelvin AA, Dunican DJ, McFarlane C, Burrows JF, Jaworski J, Stevenson NJ, Dib K, Rappoport JZ, Scott CJ, Long AD, Johnston JA. The deubiquitinating enzyme USP17 is essential for GTPase subcellular localization and cell motility. Nat Commun. 2011;2.

185. McFarlane C, McFarlane S, Paul I, Arthur K, Scheaff M, Kerr K, Stevenson M, Fennell DA, Johnston JA. The deubiquitinating enzyme USP17 is associated with non-small cell lung cancer (NSCLC) recurrence and metastasis. Oncotarget. 2013;4(10):1836-43.

186. Ramakrishna S, Suresh B, Lee EJ, Lee HJ, Ahn WS, Baek KH. Lys-63-specific Deubiquitination of SDS3 by USP17 Regulates HDAC Activity. Journal of Biological Chemistry. 2011;286(12):10505-14

187. Yan M, Luo JK, Ritchie KJ, Sakai I, Takeuchi K, Ren RB, Zhang DE. Ubp43 regulates $B C R-A B L$ leukemogenesis via the type 1 interferon receptor signaling. Blood. 2007;110(1):305-12.

188. Liu XK, Li HX, Zhong B, Blonska M, Gorjestani S, Yan M, Tian Q, Zhang DE, Lin X, Dong C. USP18 inhibits NF-kappa B and NFAT activation during Th17 differentiation by deubiquitinating the TAK1-TAB1 complex. J Exp Med. 2013:210(8):1575-90. 
189. Lu Y., Adegoke O.A.J., Nepveu A., Nakayama K.I., Bedard N., Cheng D.M., Peng J.M. and Wing S.S. USP19 Deubiquitinating Enzyme Supports Cell Proliferation by Stabilizing KPC1, a Ubiquitin Ligase for p27(Kip1) (vol 29, pg 547, 2009). Mol Cell Biol 29(11):3241-3241, 2009.

190. Hassink GC, Zhao B, Sompallae R, Altun M, Gastaldello S, Zinin NV, Masucci MG, Lindsten K. The ER-resident ubiquitin-specific protease 19 participates in the UPR and rescues ERAD substrates. Embo Rep. 2009;10(7):755-61.

191. Lee JG, Kim W, Gygi S, Ye YH. Characterization of the Deubiquitinating Activity of USP19 and Its Role in Endoplasmic Reticulum-associated Degradation. Journal of Biological Chemistry. 2014;289(6):3510-7.

192. Berthouze M, Venkataramanan V, Li Y, Shenoy SK. The deubiquitinases USP33 and USP20 coordinate beta(2) adrenergic receptor recycling and resensitization. Embo Journal. 2009;28(12):1684-96.

193. Yasunaga J, Lin FC, Lu XB, Jeang KT. Ubiquitin-Specific Peptidase 20 Targets TRAF6 and Human T Cell Leukemia Virus Type 1 Tax To Negatively Regulate NF-kappa B Signaling. J Virol. 2011;85(13):6212-9.

194. Nakagawa T, Kajitani T, Togo S, Masuko N, Ohdan H, Hishikawa Y, Koji T, Matsuyama T, Ikura T, Muramatsu M, Ito T. Deubiquitylation of histone H2A activates transcriptional initiation via trans-histone cross-talk with $\mathrm{H} 3 \mathrm{~K} 4$ diand trimethylation. Gene Dev. 2008;22(1):37-49.

195. Fan YH, Mao RF, Yu Y, Liu SF, Shi ZC, Cheng J, Zhang HY, An L, Zhao YL, Xu X, Chen ZH, Kogiso M, Zhang DK, Zhang H, Zhang PM, Jung JU, Li XN, Xu GT, Yang JH. USP21 negatively regulates antiviral response by acting as a RIG-I deubiquitinase. J Exp Med. 2014;211(2):313-28.

196. Xu GF, Tan XJ, Wang HM, Sun WJ, Shi Y, Burlingame S, Gu X, Cao GW, Zhang T, Qin J, Yang JH. Ubiquitin-specific Peptidase 21 Inhibits Tumor Necrosis Factor alpha-induced Nuclear Factor kappa B Activation via Binding to and Deubiquitinating Receptor-interacting Protein 1. Journal of Biological Chemistry. 2010;285(2):969-78.

197. Pannu J, Belle Jl, Forster M, Duerr CU, Shen SY, Kane L, Harcourt K, Fritz JH, Clare S, Nijnik A. Ubiquitin Specific Protease 21 Is Dispensable for Normal Development, Hematopoiesis and Lymphocyte Differentiation. Plos One. 2015;10(2).

198. Zhang J, Chen C, Hou XX, Gao YY, Lin F, Yang J, Gao ZM, Pan LN, Tao LQ, Wen CJ, Yao ZJ, Tsun A, Shi GC, Li B. Identification of the E3 Deubiquitinase Ubiquitin-specific Peptidase 21 (USP21) as a Positive Regulator of the Transcription Factor GATA3. Journal of Biological Chemistry. 2013;288(13): 9373-82.

199. Zhang XY, Pfeiffer HK, Thorne AW, McMahon SB. USP22, an hSAGA subunit and potential cancer stem cell marker, reverses the polycomb-catalyzed ubiquitylation of histone H2A. Cell Cycle. 2008;7(11):1522-4.

200. Dai W, Yao Y, Zhou Q, Sun CF. Ubiquitin-Specific Peptidase 22, a Histone Deubiquitinating Enzyme, Is a Novel Poor Prognostic Factor for Salivary Adenoid Cystic Carcinoma. Plos One. 2014;9(1)

201. Liang J, Zhang XL, Xie S, Zhou XP, Shi Q, Hu JX, Wang WF, Qi WF, Yu RT. Ubiquitin- specific protease 22: a novel molecular biomarker in glioma prognosis and therapeutics. Med Oncol. 2014;31(4).

202. Schrecengost RS, Dean JL, Goodwin JF, Schiewer MJ, Urban MW, Stanek TJ, Sussman RT, Hicks JL, Birbe RC, Draganova-Tacheva RA, Visakorpi T, DeMarzo AM, McMahon SB, Knudsen KE. USP22 Regulates Oncogenic Signaling Pathways to Drive Lethal Cancer Progression. Cancer Research. 2014;74(1):272-86.

203. Zhang L, Lubin A, Chen H, Sun ZY, Gong F. The deubiquitinating protein USP24 interacts with DDB2 and regulates DDB2 stability. Cell Cycle. 2012; 11(23):4378-84.

204. Zhong HJ, Wang D, Fang LR, Zhang H, Luo R, Shang M, Ouyang C, Ouyang HP, Chen HC, Xiao SB. Ubiquitin-Specific Proteases 25 Negatively Regulates Virus-Induced Type I Interferon Signaling. Plos One. 2013;8(11).

205. Blount JR, Burr AA, Denuc A, Marfany G, Todi SV. Ubiquitin-Specific Protease 25 Functions in Endoplasmic Reticulum-Associated Degradation. Plos One. 2012;7(5).

206. Zhong B, Liu XK, Wang XH, Liu XD, Li HX, Darnay BG, Lin X, Sun SC, Dong C. Ubiquitin-Specific Protease 25 Regulates TLR4-Dependent Innate Immune Responses Through Deubiquitination of the Adaptor Protein TRAF3. Sci Signal. 2013;6(275)

207. Dirac AMG, Bernards R. The Deubiquitinating Enzyme USP26 Is a Regulator of Androgen Receptor Signaling. Mol Cancer Res. 2010;8(6):844-54.

208. Paduch DA, Mielnik A, Schlegel PN. Novel mutations in testis-specific ubiquitin protease 26 gene may cause male infertility and hypogonadism. Reprod Biomed Online. 2005;10(6):747-54.

209. Wang PJ, McCarrey JR, Yang F, Page DC. An abundance of X-linked genes expressed in spermatogonia. Nat Genet. 2001;27(4):422-6.
210. Atanassov BS, Mohan RD, Lan XJ, Kuang XH, Lu Y, Lin K, Mclvor E, Li WQ, Zhang Y, Florens L, Byrum SD, Mackintosh SG, Calhoun-Davis T, Koutelou E, Wang L, Tang DG, Tackett AJ, Washburn MP, Workman JL, Dent SYR. ATXN7L3 and ENY2 Coordinate Activity of Multiple H2B Deubiquitinases Important for Cellular Proliferation and Tumor Growth. Mol Cell. 2016;62(4):558-71.

211. Popov N, Herold S, Llamazares M, Schulein C, Eilers M. Fbw7 and Usp28 regulate Myc protein stability in response to DNA damage. Cell Cycle. 2007; 6(19):2327-31.

212. Zhang D, Zaugg K, Mak TW, Elledge SJ. A role for the deubiquitinating enzyme USP28 in control of the DNA-damage response. Cell. 2006;126(3): $529-42$

213. Martin Y, Cabrera E, Amoedo H, Hernandez-Perez S, Dominguez-Kelly R, Freire R. USP29 controls the stability of checkpoint adaptor Claspin by deubiquitination. Oncogene. 2015;34(8):1058-63.

214. Liu JH, Chung HJ, Vogt M, Jin YT, Malide D, He LS, Dundr M, Levens D. JTV1 co-activates FBP to induce USP29 transcription and stabilize p53 in response to oxidative stress. Embo Journal. 2011;30(5):846-58.

215. Nakamura N, Hirose S. Regulation of mitochondrial morphology by USP30, a deubiquitinating enzyme present in the mitochondrial outer membrane. Mol Biol Cell. 2008;19(5):1903-11.

216. Gersch M, Gladkova C, Schubert AF, Michel MA, Maslen S, Komander D. Mechanism and regulation of the Lys6-selective deubiquitinase USP30. Nat Struct Mol Biol. 2017;24(11):920-+.

217. Yue W, Chen ZH, Liu HY, Yan C, Chen M, Feng D, Yan CJ, Wu H, Du L, Wang $Y Y$, Liu JH, Huang XH, Xia LX, Liu L, Wang XH, Jin HJ, Wang J, Song ZY, Hao $\mathrm{XJ}$, Chen Q. A small natural molecule promotes mitochondrial fusion through inhibition of the deubiquitinase USP30. Cell Res. 2014;24(4):482-96.

218. Ye SA, Lawlor MA, Rivera-Reyes A, Egolf S, Chor S, Pak K, Ciotti GE, Lee AC, Marino GE, Shah J, Niedzwicki D, Weber K, Park PMC, Alam MZ, Grazioli A, Haldar M, Xu MS, Perry JA, Qi J, Eisinger-Mathason TSK. YAP1-Mediated Suppression of USP31 Enhances NF kappa B Activity to Promote Sarcomagenesis. Cancer Research. 2018;78(10):2705-20.

219. Akhavantabasi S, Akman HB, Sapmaz A, Keller J, Petty EM, Erson AE. USP32 is an active, membrane-bound ubiquitin protease overexpressed in breast cancers. Mamm Genome. 2010;21(7-8):388-97.

220. Li J, D'Angiolella V, Seeley ES, Kim S, Kobayashi T, Fu WX, Campos El, Pagano M, Dynlacht BD. USP33 regulates centrosome biogenesis via deubiquitination of the centriolar protein CP110. Nature. 2013;495(7440):255-9.

221. Shenoy SK, Modi AS, Shukla AK, Xiao KH, Berthouze M, Ahn S, Wilkinson KD, Miller WE, Lefkowitz RJ. beta-Arrestin-dependent signaling and trafficking of 7-transmembrane receptors is reciprocally regulated by the deubiquitinase USP33 and the E3 ligase Mdm2. P Natl Acad Sci USA. 2009;106(16):6650-5.

222. Li ZB, Na X, Wang DK, Schoen SR, Messing EM, Wu G. Ubiquitination of a novel deubiquitinating enzyme requires direct binding to von HippelLindau tumor suppressor protein. Journal of Biological Chemistry. 2002; 277(7):4656-62.

223. De Pitta C, Tombolan L, Dell'Orto MC, Accordi B, te Kronnie G, Romualdi C, Vitulo N, Basso G, Lanfranchi G. A leukemia-enriched cDNA microarray platform identifies new transcripts with relevance to the biology of pediatric acute lymphoblastic leukemia. Haematol-Hematol J. 2005;90(7):890-8.

224. Lui TTH, Lacroix C, Ahmed SM, Goldenberg SJ, Leach CA, Daulat AM, Angers S. The Ubiquitin-Specific Protease USP34 Regulates Axin Stability and Wnt/ beta-Catenin Signaling. Mol Cell Biol. 2011;31(10):2053-65.

225. Liu CY, Wang LN, Chen WW, Zhao SH, Yin CL, Lin Y, Jiang AL, Zhang PJ. USP35 activated by miR let-7a inhibits cell proliferation and NF-kappa B activation through stabilization of ABIN-2. Oncotarget. 2015;6(29):27891-906.

226. Park J, Kwon MS, Kim EE, Lee H, Song EJ. USP35 regulates mitotic progression by modulating the stability of Aurora B. Nat Commun. 2018;9.

227. Paulsson K, Bekassy AN, Olofsson T, Mitelman F, Johansson B, Panagopoulos I. A novel and cytogenetically cryptic t(7;21)(p22;q22) in acute myeloid leukemia results in fusion of RUNX1 with the ubiquitin-specific protease gene USP42. Leukemia. 2006;20(2):224-9.

228. Zamecnikova A, Al BS. A Novel and Cytogenetically Cryptic t(7;21)(q36.1;q22) Disrupting <it> in Acute Myeloid Leukemia. Cytogenet Genome Res. 2018; 156(3):140-3.

229. Stegmeier F, Rape M, Draviam VM, Nalepa G, Sowa ME, Ang XLL, McDonald ER, Li MZ, Hannon GJ, Sorger PK, Kirschner MW, Harper JW, Elledge SJ. Anaphase initiation is regulated by antagonistic ubiquitination and deubiquitination activities. Nature. 2007:446(7138):876-81.

230. Parsons Ut, Dianova II, Khoronenkova SV, Edelmann MJ, Kessler BM, Dianov GL. USP47 Is a Deubiquitylating Enzyme that Regulates Base Excision Repair 
by Controlling Steady-State Levels of DNA Polymerase beta. Mol Cell. 2011; 41(5):609-15.

231. Zhang Z, Jones A, Joo HY, Zhou DW, Cao Y, Chen SX, Erdjument-Bromage H, Renfrow M, He H, Tempst P, Townes TM, Giles KE, Ma LG, Wang HB. USP49 deubiquitinates histone $\mathrm{H} 2 \mathrm{~B}$ and regulates cotranscriptional premRNA splicing. Gene Dev. 2013;27(14):1581-95.

232. Aressy B, Jullien D, Cazales M, Marcellin M, Bugler B, Burlet-Schiltz O, Ducommun B. A screen for deubiquitinating enzymes involved in the $G(2)$ / M checkpoint identifies USP50 as a regulator of HSP90-dependent Wee1 stability. Cell Cycle. 2010;9(18):3815-22.

233. Pereg Y, Liu BY, O'Rourke KM, Sagolla M, Dey A, Komuves L, French DM, Dixit VM. Ubiquitin hydrolase Dub3 promotes oncogenic transformation by stabilizing Cdc25A. Nat Cell Biol. 2010;12(4):400-U226.

234. Delgado-Diaz M.R., In Y.M., Berg A., Freire R. and Smits V.A.J. Dub3 controls DNA damage signalling by direct deubiquitination of H2AX (vol 8, pg 884, 2014). Mol Oncol 11(8):1112-1112, 2017.

235. Ke HN, Augustine CK, Gandham VD, Jin JY, Tyler DS, Akiyama SK, Hall RP, Zhang JY. CYLD Inhibits Melanoma Growth and Progression through Suppression of the JNK/AP-1 and beta 1-Integrin Signaling Pathways. J Invest Dermatol. 2013;133(1):221-9.

236. Friedman CS, O'Donnell MA, Legarda-Addison D, Ng A, Cardenas WB, Yount JS, Moran TM, Basler CF, Komuro A, Horvath CM, Xavier R, Ting AT. The tumour suppressor CYLD is a negative regulator of RIG-I-mediated antiviral response. Embo Rep. 2008;9(9):930-6.

237. Zhang MY, Wu XF, Lee AJ, Jin W, Chang M, Wright A, Imaizumi T, Sun SC. Regulation of I kappa B kinase-related kinases and antiviral responses by tumor suppressor CYLD. Journal of Biological Chemistry. 2008;283(27): 18621-6.

238. Kovalenko A, Chable-Bessia C, Cantarella G, Israel A, Wallach D, Courtois G. The tumour suppressor CYLD negatively regulates NF-kappa B signalling by deubiquitination. Nature. 2003;424(6950):801-5.

239. Wright A, Reiley WW, Chang M, Jin W, Lee AJ, Zhang MY, Sun SC. Regulation of early wave of germ cell apoptosis and spermatogenesis by deubiquitinating enzyme CYLD. Dev Cell. 2007;13(5):705-16.

Ready to submit your research? Choose BMC and benefit from:

- fast, convenient online submission

- thorough peer review by experienced researchers in your field

- rapid publication on acceptance

- support for research data, including large and complex data types

- gold Open Access which fosters wider collaboration and increased citations

- maximum visibility for your research: over $100 \mathrm{M}$ website views per year

At $\mathrm{BMC}$, research is always in progress.

Learn more biomedcentral.com/submissions 